\title{
A Comparative in vitro Study of the Effect of Eosin B on Asexual Blood Stages and Gametocyte of Plasmodiun falciparum
}

\author{
Alireza Sadeghi Tafreshi ${ }^{1}$ (D) Zahra Zamani $^{2}$, Marjan Sabbaghian ${ }^{1,3 *(D)}$, Ramezan Ali Khavari-nejad ${ }^{1}$, \\ Mohammad Arjmand ${ }^{2}$ D
}

1. Department of Biology, Science and Research Branch, Islamic Azad University, Tehran, Iran

2. Department of Biochemistry, Pasteur Institute of Iran, Tehran, Iran

3. Department of Andrology, Reproductive Biomedicine Research Center, Royan Institute for Reproductive Biomedicine, ACECR, Tehran, Iran

\section{ABSTRACT}

Background and Aim: Malaria is one of the most life-threatening infectious diseases worldwide. Transmission of the parasite from human to vector mosquitoes is carried out by the gametocyte of the Plasmodium parasite, while these cells are not involved in the symptoms of the disease. The control of the human to mosquito transmission stage of the parasite life cycle by antigametocyte drugs is currently under increasing scrutiny in an effort to eradicate the disease globally. In this study the gametocytocidal activity of eosin B on asexual blood stages and gametocytes of Plasmodium falciparum has been probed.

Materials and Methods: The parasite Plasmodium falciparum 3D7 was first cultured and then gametocytogenesis was induced to obtain gametocyte cells. After microscopically studying the developmental stages of the parasite during the culture of the parasite, eosin B was tested on blood and sexual parasites and the viability was assessed by lactate dehydrogenase assay and the results were compared for the two groups.

Results: Mature gametocytes were produced during 12 days. The blood parasites in culture were increased until day 4 and then gradually diminished. The results of lactate dehydrogenase assay showed a stronger effect of eosin $\mathrm{B}$ on gametocytes $\left(\mathrm{IC}_{50}=23 \mathrm{nM}\right)$ than asexual blood stages $\left(\mathrm{IC}_{50}=133 \mathrm{nM}\right)$.

Conclusion: Due to the rarity of anti-gametocyte drugs and importance of these intervention on malaria elimination, eosin $\mathrm{B}$ appears to be a suitable candidate for combination therapy against Plasmodium falciparum gametocytes.

Keywords: Malaria, Plasmodium falciparum, Gametocyte, Eosin B, Lactate dehydrogenase

Received: 2020/08/01; Accepted: 2020/12/27; Published Online: 2021/04/09

\begin{tabular}{|c|c|}
\hline Corresponding Information: & $\begin{array}{l}\text { Marjan Sabbaghian, Department of Andrology, Reproductive Biomedicine Research Center, Royan Institute for Reproductive } \\
\text { Biomedicine, ACECR, Tehran, Iran. Email: marjan.sabbaghian@gmail.com }\end{array}$ \\
\hline (c) (i) (1) & $\begin{array}{l}\text { is is an original open-access article distributed under the terms of the Creative Cor } \\
\text { istribution of the material just in noncommercial usages with proper citation. }\end{array}$ \\
\hline
\end{tabular}

Use your device to scan and read the article online

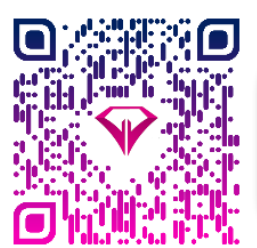

Sadeghi Tafreshi A, Zamani Z, Sabbaghian M, Khavari-Nejad R A, Arjmand M. A Comparative in vitro Study of the Effect of Eosin B on Asexual Blood Stages and Gametocyte of Plasmodiun falciparum. Iran J Med Microbiol. 2021; 15 (2):173-188

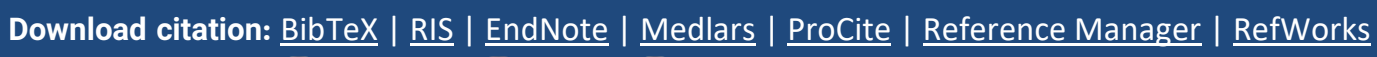
Send citation to:
8 Mendeley
(2) Zotero
(B) RefWorks

\section{Introduction}

Malaria is a preventable, treatable, and lifethreatening disease caused by disease-related parasites, which are transmitted to humans by mosquito bites. According to the World Health Organization (WHO) annual report on malaria, in 2018 there were about 228 million cases of malaria and 405,000 deaths due to this disease worldwide (1). According to the official report of the WHO in 2017, 57 cases of native malaria were registered in Iran, which shows a significant decrease compared to 1800 cases 
in 2010 and 12000 cases in 2000. In addition, no deaths from malaria were reported in Iran in 2017 (2).

In the complex life cycle of Plasmodium parasites, asexual blood stage parasites are responsible for the development of clinical signs and symptoms of the disease, and therefore major antimalarial drugs target this part of the parasite's life cycle and are used to improve the symptoms of the disease. Gametocytes, which are involved in the sexual part of the parasite's life cycle, play no role in causing the symptoms of the disease, but they play a role in transmission of the parasite from the human host to the Anopheles mosquito vector (3).

Drugs that can reduce gametocytogenesis, or can kill gametocytes, called gametocytocides, are very effective in counteracting the spread of malaria but due to lack of proper quantitative high throughput screening assays are still being studied. These transmission-blocking antimalarial drugs can work by targeting the following: 1. Effective and complete killing of adult gametocytes when they form in a human host. 2. Inhibition of gametocyte growth to oocytes and eventually sporozoites in mosquitoes. This requires enough medicine to reach the midgut of mosquito from the blood sample (4).

Gametocyte production occurs through five stages of maturation (I to $V$ ), and stage $V$ is the only form that can infect mosquitoes. For $P$. falciparum, these mature gametocytes appear 12 days after symptoms and circulate for an average of 2.5 to 6.5 days, lasting up to 22 days. Thus, circulating gametocytes can maintain the process of malaria transmission from host to vector after drug treatment, which eliminates the symptoms of the disease (5).

Most currently approved antimalarial drugs, including artemisinin (ART)-based combination therapies (ACT), are effective only against blood stages and early-stage gametocytes up to stage III and possibly stage IV gametocyte maturation. In addition, some drug treatments such as chloroquine (CQ) and sulfadoxine-pyrimethamine induce gametocytogenesis and therefore effectively increase the number of cases of disease transmission and the rate of new infections (6).

Currently, the only antimalarial drug that has effective gametocytocidal activity is primaquine, which acts against gametocytes of all Plasmodium spp. and is the WHO recommended option against $P$. falciparum gametocytes. Unfortunately, the possibility of using this drug is also limited - due to the possibility of acute hemolytic anemia associated with deficiency of glucose 6-phosphate dehydrogenase (G6PD) enzyme $(7,8)$. Because of the risks of the primaquine treatment, the new transmission-blocking interventions to achieve the ultimate goal of eradicating malaria are currently receiving considerable attention. Extensive studies are recently underway on the biological characteristics of the transmission stages and the development of in vitro assays focusing on the late-stage gametocyte production, mature gametocytes lethality, and gametocyte-oocyte / sporozoite transmission (3). One of the new tests used for the parasite gametocyte stage is the parasite viability assay using the lactate dehydrogenase enzyme (LDH) (9). Lactate dehydrogenase is the enzyme located at the end of the anaerobic pathway of Embden-Meyerhof glycolysis and plays a critical role in the carbohydrate metabolism of human malaria parasites. LDH has been shown to play an important role in malaria infection and may be a possible drug target for malaria treatment (10). In addition to being a marker of parasite viability, P. falciparum LDH ( $P f L D H)$ is also an interesting diagnostic biomarker, as it is highly conserved among all four species known to infect humans (11). However, PfLDH activity in the host's circulation is cleared within 24 hours after successful treatment, resulting in much less false-positive diagnosis due to the continued presence of a biomarker after removal of the infection (12).

To achieve malaria elimination, antimalarial drugs or combination therapies must not only eliminate the asexual stages of the parasite that are responsible for the clinical symptoms of disease, but must also be able to clear the sexual stages of the parasite that maintain the host-to-vector transmission stage. Therefore, the results of such studies can be a way to prepare novel transmission-blocking antimalarial drugs.

Eosin B (EO) is a laboratory dye that has previously been proposed for its anti-parasitic ability through molecular docking methods and its antimalarial effect has been studied in in vitro and rodent malaria models (13-16). In the present study, after culturing $P$. falciparum gametocytes and carefully examining the blood and sex stages of the parasite during the culture period, the EO compound was investigated as a new anti-gametocyte agent and the results of treatment of asexual and sexual stages of the parasite by eosin $B$ using LDH test eosin B has been compared.

\section{Materials and Methods}

\section{In vitro Culture of $P$. falciparum Asexual Stage Parasites}

Culture of $P$. falciparum strain 3D7 was performed at $37^{\circ} \mathrm{C}$ in human type $\mathrm{O}^{+} \mathrm{RBCs}$ at $5 \%$ haematocrit. Culture medium contained complete medium including RPMI 1640 medium (Sigma-Aldrich), $25 \mathrm{mM}$ HEPES (Sigma-Aldrich), $0.2 \%$ D-glucose (SigmaAldrich), hypoxanthine $200 \mu \mathrm{M}$ (Sigma-Aldrich), 0.2\% Sodium hydrogen carbonate (Sigma-Aldrich), gentamicin (Invitrogen) $40 \mathrm{mg} . \mathrm{L}^{-1}, 0.5 \%$ albumex 
(Invitrogen) and $10 \%$ (vol/vol) $\mathrm{O}^{+}$human serum. The parasite was cultured in an atmosphere containing $90 \% \mathrm{~N}_{2}, 5 \% \mathrm{O}_{2}$ and $5 \% \mathrm{CO}_{2}(17,18)$.

The culture medium was daily gassed and replaced with a new medium (heated to $37^{\circ} \mathrm{C}$ ). Parasite proliferation on each day of the culture period was microscopically examined by taking Giemsa-stained thin blood smear. To synchronize asexual culture, 5\% D-sorbitol was used to prepare the parasite in the early trophozoite stage (ring) (19).

\section{Induction of Gametocytogenesis and Gametocyte Culture}

Asexual parasites were cultured to increase the parasitemia to $6-10 \%$. Then the parasitemia was descended to $0.5 \%$ (in $6 \%$ hematocrit). Cultures were maintained in an atmosphere containing $90 \% \mathrm{~N}_{2}, 5 \%$ $\mathrm{O}_{2}$ and $5 \% \mathrm{CO}_{2}$ without shaking. The cultures were also maintained at $37^{\circ} \mathrm{C}$ during daily media change. After 72 hours, the hematocrit was reduced to $3 \%$ (day 0 ). Gametocytogenesis was subsequently monitored by daily microscopic examination of the culture medium. On days 6 to 9, asexual forms were removed by treatment with $100 \mu \mathrm{g} . \mathrm{mL}^{-1}$ heparin (Sigma-Aldrich). Gametocytes were monitored daily by examining Giemsa-stained thin blood smear until they reached stage $\mathrm{V}$ and were prepared for further testing (20).

Quality Control of Functionally Viable Mature Stage V Gametocyte Production and Male Gamete Exflagellation

After production of stage $\mathrm{V}$ gametocytes, during daily change of culture medium, the precipitated blood cells were resuspended. $200 \mu \mathrm{L}$ was taken from the culture medium and quickly transferred to a $1.5 \mathrm{ml}$ tube prewarmed to $37^{\circ} \mathrm{C}$. After treating the sample with $50 \mu \mathrm{M}$ xanthurenic acid in an exflagellation buffer (RPMI 1640 with $25 \mathrm{mM}$ HEPES, 0.2\% sodium bicarbonate, $\mathrm{pH} 8$ ), the culture medium was placed in a microcentrifuge at $2000 \mathrm{~g}$ for $30 \mathrm{~s}$ at room temperature. Then a thin blood smear was prepared from it and stained with Giemsa and then a light microscope was used to control the quality of exflagellation (21).

\section{Eosin B Test on the P. falciparum Ring Stage}

In a 96-well plate, $20 \mu \mathrm{L}$ of culture containing added asexual parasites was added to all rows except one row belonging to the control group. All samples were repeated in triplicate and placed in a $\mathrm{CO}_{2}$ incubator for 48 hours.

Eosin B Test on Plasmodium Falciparum Gametocyte

In a 96-well plate, $20 \mu \mathrm{L}$ of gametocyte-containing culture was added to all rows except one row belonging to the control group. All samples were repeated triplicate and placed in a $\mathrm{CO}_{2}$ incubator for 42 hours.

Parasitemia and Gametocytemia Evaluation by $\boldsymbol{P}$. falciparum Lactate Dehydrogenase (PfLDH) Assay

Parasitemia evaluation by lactate dehydrogenase assay is a high-throughput screening assay for antimalarial agents. For this purpose, $100 \mu \mathrm{L}$ of Malstat reagent (1.57 g Tris $\mathrm{HCl}, 2 \mathrm{~g}$ L-lactic acid, 200 $\mu \mathrm{L}$ Triton X-100 in $85 \mathrm{ml}$ double-distilled water, $66 \mathrm{mg}$ 3-acetylpyridine adenine dinucleotide (APAD), $\mathrm{pH} 9.1$ ) was added to the 96 -well microplate. Then 20 microliters of infected or uninfected red blood cells were added. The plate was incubated at room temperature and gently shaken for a few minutes to dissolve the red blood cells. During incubation, equal volumes of Nitro Blue Tetrazolium (NBT) and Phenazine Ethosulphate (PES) were mixed away from light and $20 \mu \mathrm{L}$ of the mixture was added to the wells. The plate was placed away from light. After 30 to 60 minutes, the color change was controlled so that the color tended to dark purple. The plate was read using a BioTek PowerWave XS Microplate Reader at $650 \mathrm{~nm}$. Uninfected red blood cells were used as a reference. Viability percentage was calculated from the following formula $(9,22,23)$

Viability $\%=100 \times\left(\right.$ ODtreated sample $\left.-\mu_{c_{-}}\right) /\left(\mu_{c^{+}}-\mu_{c-}\right.$ $\mu_{\mathrm{c}^{+}}=$means $(\mu)$ of OD control gametocytes $(\mathrm{c}+)$

$\mu_{\mathrm{c}-}=$ means $(\mu)$ of OD blank uninfected RBCs (c-)

Statistical analysis: In this study, the tests were repeated 3 times and the results were analyzed by one-way ANOVA at a significance level of $p$-value $<0.05$ using GraphPad Prism Version 7.05 software.

\section{Results}

\section{Culture of Asexual Parasites}

After adjusting the culture conditions and using the appropriate protocol, asexual parasites were cultured. Figure 1 shows the number of parasites during the culture period 


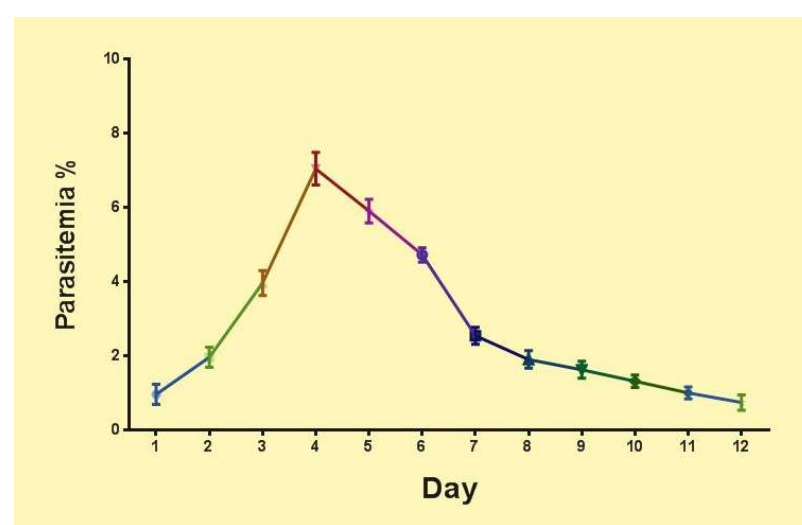

Figure 1. Asexual blood stages parasitemia during gametocyte culture.

As can be seen in the diagram, the number of parasites gradually increases from the beginning of the culture period and reaches its maximum on day 4 . Then their number gradually decreased and the parasitemia of asexual sex blood parasites was diminished.

\section{Gametocyte Culture}

Figure 2 shows which stages of the parasite are found in the culture medium on different days of the culture period.

The diagram shows the asexual stages around the first to fifth days and the early (I, II and III) and late stage (IV and V) gametocytes were observed in the culture on the second to eighth and seventh to twelfth days, respectively.

\section{Changes in the Number of Gametocytes During the Culture Period}

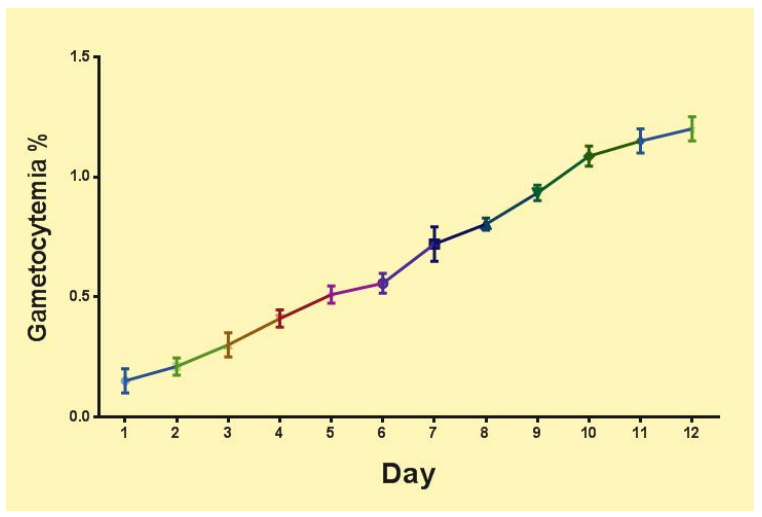

Figure 3. Percentage of gametocytemia during gametocyte culture.

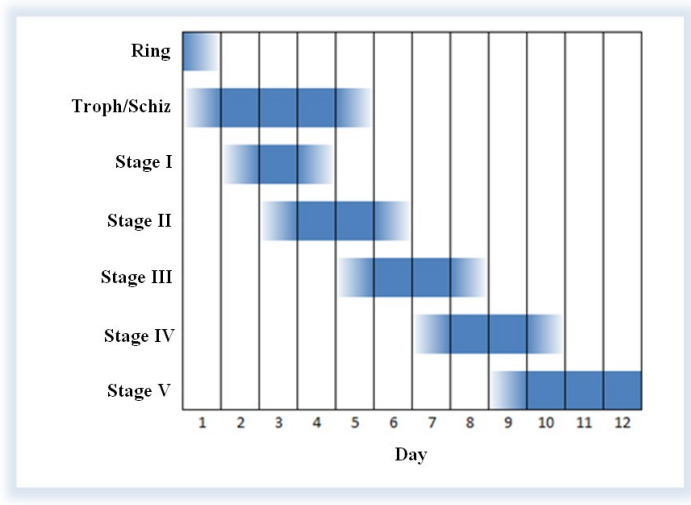

Figure 2. Different stages of $P$. falciparum 3D7 during the gametocyte culture period.

As can be seen in Figure 3 , the number of gametocytes gradually increases during the culture period and reaches its maximum on day 12 at the same time as the gametocyte matures (stage $\mathrm{V}$ ). In this condition, the gametocytes are capable of infecting the vector and are ready to perform an antigametocyte reagent test.

The Effect of Eosin B on Asexual Stages of $\boldsymbol{P}$. falciparum

Figure 4 shows the effect of EO on the asexual stages of $P$. falciparum. Compared to the control group, the viability decreased for each test group by increasing the concentration of EO. The $\mathrm{IC}_{50}$ of EO for the asexual stages of the parasite is $133 \mathrm{nM}$.

Figure 5 compares the effects of EO and the control drugs $C Q$ and $A R T$ on the parasite ring of $P$. falciparum 3D7. The $I C_{50}$ level of EO is higher than standard control drugs and is $133 \mathrm{nM}$. IC $\mathrm{C}_{50}$ values for $\mathrm{CQ}$ and ART were 6.8 and $7.6 \mathrm{nM}$, respectively.

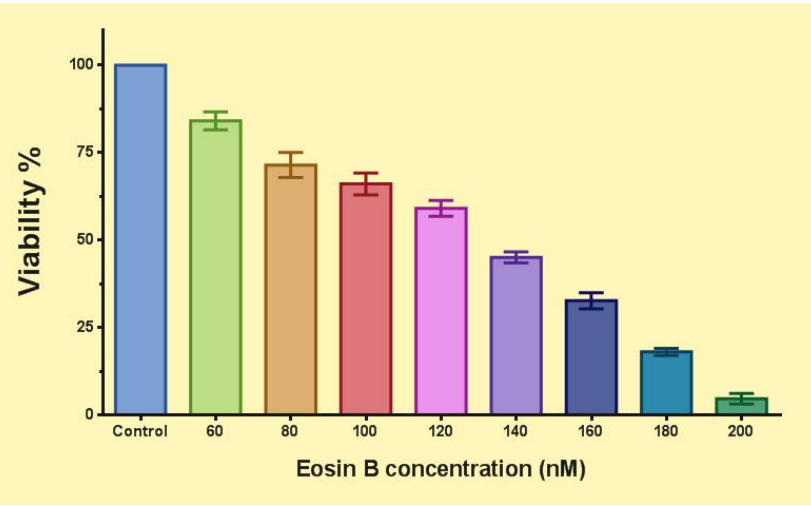

Figure 4. The effect of eosin B on the ring of $P$. falciparum 3D7 parasite. The viability (\%) compared to the control group is shown for each test group.

(Means \pm SEM $(n=5 \& P<0.05)$, One Way-ANOVA test with GraphPad Prism version (7.05) 


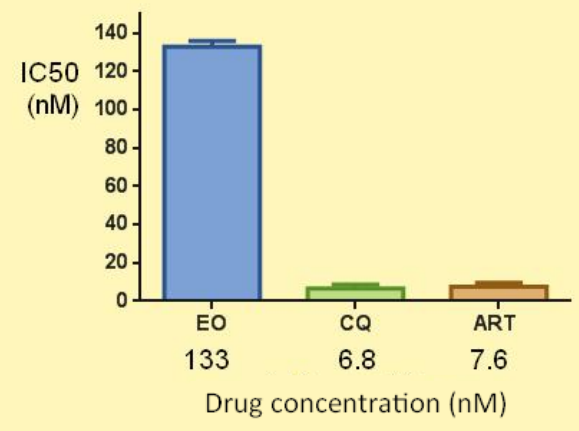

Figure 5. Comparison of the effect of eosin B (EO) and control drugs chloroquine (CQ) and artemisinin (ART) on $P$. falciparum 3D7 parasite ring. $I C_{50}$ values for $E O, C Q$ and $A R T$ are shown below each group. (Means \pm SEM $(n=5 \& P<0.05)$, One Way-ANOVA test with GraphPad Prism version 7.05)

\section{The Effect of Eosin B on P. falciparum Gametocytes}

Figure 6 shows the effect of EO on P. falciparum parasite gametocytes. Compared to the control group, the viability decreased for each test group by increasing the concentration of EO. The $\mathrm{IC}_{50}$ of EO for the parasite gametocyte is $23 \mathrm{nM}$.

Figure 7 compares the effects of EO and the control drugs $C Q$ and ART on P. falciparum 3D7 gametocytes. The $\mathrm{IC}_{50}$ value of EO is lower than $23 \mathrm{nM}$ compared to standard control drugs. IC 50 values for $\mathrm{CQ}$ and ART were 41 and $85 \mathrm{nM}$, respectively. Contrary to the results of the EO test on the blood stages of the parasite, it was observed that EO inhibited the gametocyte growth at a lower dose than standard drugs, indicating a potent inhibitory effect of EO on the $P$. falciparum 3D7 gametocyte.

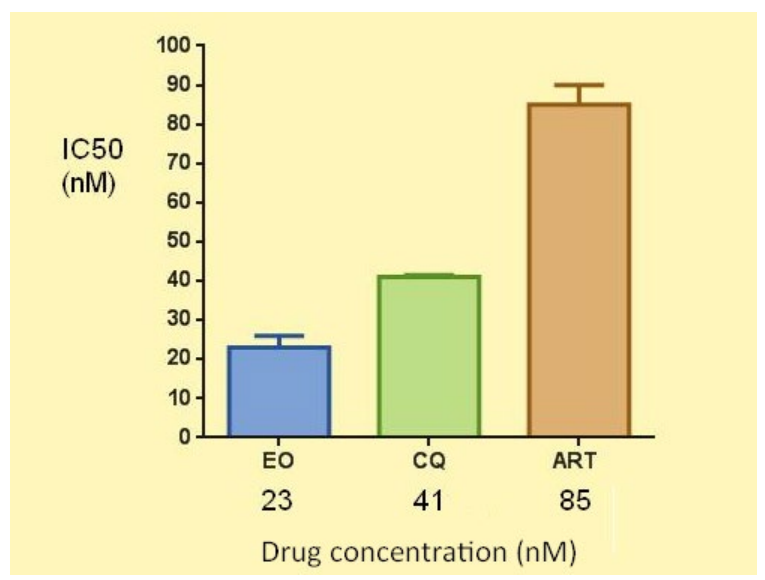

Figure 7. Comparison of the effect of eosin $B(E O)$ and chloroquine (CQ) and artemisinin (ART) control drugs on $P$. falciparum 3D7 parasite gametocytes. IC 50 values for EO, CQ and ART are shown below each group.(Means \pm SEM $(n=5 \& P<0.05)$

One Way-ANOVA test with Graph Pad prism version 7.05)

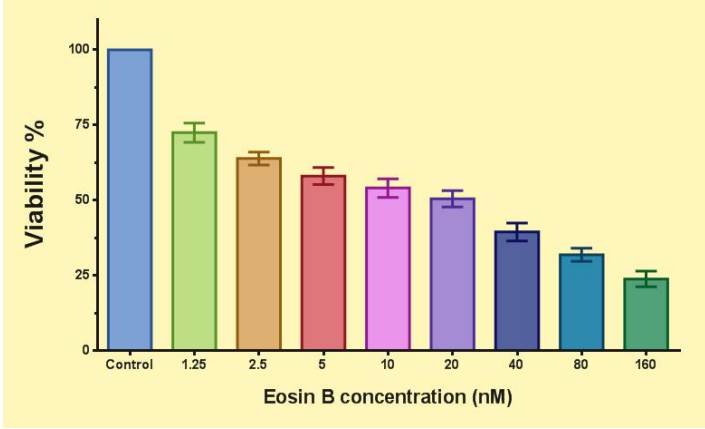

Figure 6. Effect of eosin B on P. falciparum 3D7 gametocyte. (Means \pm SEM ( $n=5 \& P<0.05)$, One WayANOVA test with Graph Pad prism version 7.05)

\section{Discussion}

Sustained control of malaria is achieved if, in addition to using therapeutic strategies that target the asexual forms that cause the symptoms of malaria, the sexual forms of the parasite, which are the same as gametocytes, are also targeted by drugs that control the parasite transmission stage (24). In the present study, by an improved protocol of using heparin, induction of gametocytogenesis and production of parasite sex cells was performed to test a new compound in the treatment of $P$. falciparum strain 3D7. It should also be noted that the control of cultured gametocytes should be done carefully so that at least $90 \%$ of gametocytes have reached full IV-V growth stage in order to test the drug composition (25). Also, direct comparison of data from studies of drug discovery against gametocytes is difficult due to several factors, including the following: 1- Parasite strain used; 2- Protocol used to induce gametocytogenesis; 3- Combination of culture medium Used; 4- Gametocyte isolation protocols; 5Developmental stage of gametocytes in the study; 6Principles of assays used in the experiment; 7Presence or absence of erythrocytes; 8- Number of gametocytes in each test well; 10 - Concentration of tested compounds; 11- Duration of drug administration; 12- How to express the obtained data such as inhibition percentage in a certain concentration or $\mathrm{IC}_{50}$ alone, etc. (14).

EO has shown a significant inhibitory effect on Toxoplasma gondii and the blood stage of $P$. falciparum. IC $\mathrm{C}_{50}$ values for EO in $T$. gondii and $P$. falciparum asexual blood stages were $180 \mu \mathrm{M}$ and 124 $\mathrm{nM}$, respectively $(13,14)$. Since the $\mathrm{IC}_{50}$ of EO for $P$. falciparum gametocytes is $23 \mathrm{nM}$, EO can inhibit gametocytes more severely than asexual blood parasites. Due to the fact that many antimalarial drugs do not have much ability to eliminate the sexual stage of the parasite and even some (such as CQ) induce 
gametocyte production and increase the number of gametocytes (26), the significant effect of EO on gametocytes and its anti-gammocyte effect in vitro can be considered for the preparation of drugs that block human-to-mosquito transmission.

Methylene blue, which is a dye used in the laboratory, has an inhibitory effect against all stages of $P$. falciparum (4) and has been proposed as a strong inhibitor of the transition from host to vector (27). Also, its significant effect on gametocytes of this parasite through morphological deformation of gametocytes has been recently reported (28). The IC $\mathrm{I}_{50}$ value of methylene blue for $P$. falciparum gametocyte in vitro is $12.49 \mathrm{nM}$ (24). The $\mathrm{IC}_{50}$ value for $E O$ is close to this combination, indicating the high efficacy of EO against the sexual stage of the parasite.

Compared to the main antimalarial drugs, it can be mentioned that ART, which is an important antimalarial drug, especially in combination therapies, as well as cases of severe and drug-resistant malaria, cannot directly inhibit gametocytes in the patient's body, but it reduces the gametocytemia indirectly by eliminating the blood stages of the parasite (6). The effect of Artesunate, a derivative of ART, on $P$. falciparum gametocytes has been previously reported in vitro with an $\mathrm{IC}_{50}$ of $102.3 \mathrm{nM}$ (24). Also, primaquine, which is the only drug used clinically to remove gametocytes, has a much higher $\mathrm{IC}_{50}$ in vitro than $\mathrm{EO}$ (IC $5015 \mu \mathrm{M})$. Unfortunately, the use of this drug is also limited due to the possibility of hemolytic anemia in people with deficiency in glucose-6-phosphate dehydrogenase (7). Other drugs used clinically against malaria blood stages include quinine and mefloquine, each of which has a higher $\mathrm{IC}_{50}$ than eosin with an $\mathrm{IC}_{50}$ of $50 \mathrm{nM}$ (29). Hydroxychloroquine is another derivative of the important antimalarial drug (CQ) in vitro with an $\mathrm{IC}_{50}$ of $22.78 \mathrm{nM}$ against gametocytes has shown its inhibitory effect (24), which is very close to $I_{50}$ EO. Therefore, the efficacy of EO against the sexual stage of $P$. falciparum is close to or higher than some of the important known antimalarial drugs. Therefore, due to the possibility of using EO as an oral drug and its strong anti-gametocytic effect compared to some conventional drugs, this combination can be considered as a suitable candidate for use as a drug that blocks the transmission from host to vector.

\section{Conclusion}

Given the significant effect of EO on the number of gametocytes and also the comparison of its effect on the blood stage of $P$. falciparum in vitro, this combination will probably be able to effectively control the transmission from human host to mosquito vector. This effect can be tested by infecting Anopheles mosquitoes, which can be considered in future research using the standard MembraneFeeding Assay test, which is the gold standard test for blocking transmission to be examined (30). Given the lack of known pharmacological agents that block human-to-vector transmission, identifying the EO compound as an antigamocyte agent could be important for future research.

\section{Acknowledgment}

None.

\section{Conflict of Interest}

The authors declared no conflict of interest. 


$$
\begin{aligned}
& \text { مجله ميكروبشناسى يزشكى ايران } \\
& \text { سال ه| _ شماره Y _ فروردين و ارديبهشت .. } \\
& \text { Journal homepage: www.ijmm.ir }
\end{aligned}
$$

يك مطالعه مقايسهاى در مورد تاثير ائوزين B بر مراحل خونى غيرجنسى و كامتوسيت انكل

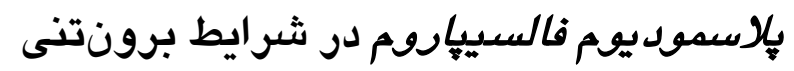

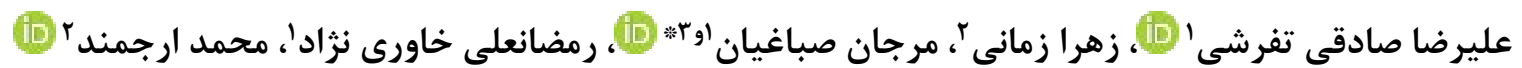

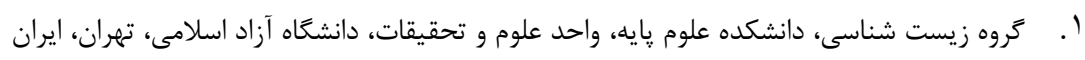

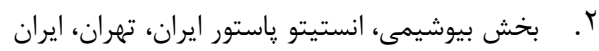

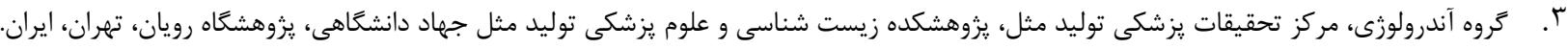

\section{جكيده}

زمينه و اهداف: بيمارى مالاريا بهعنوان يكى از تهديدكنندهترين بيمارىهاى عفونى در سطح جهان مطرح است. انتقال

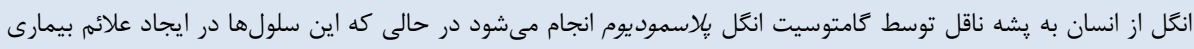

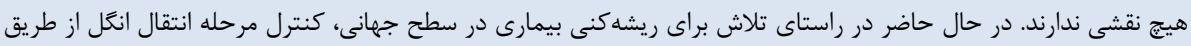

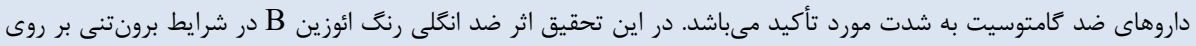

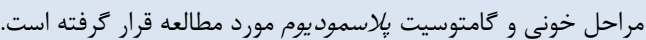

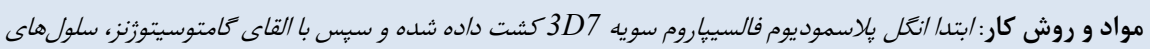

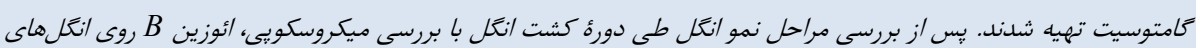

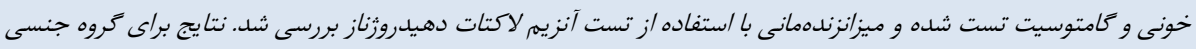
و غيرجنسى مقايسه كرديد.

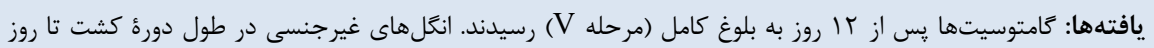

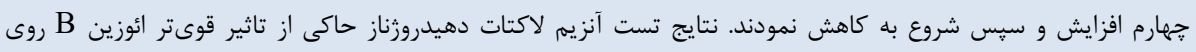

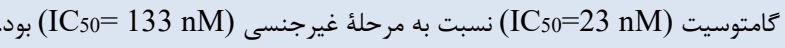

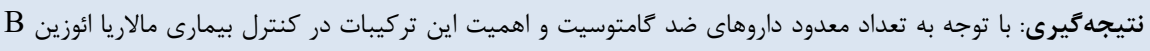

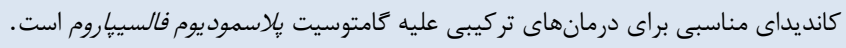

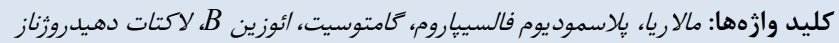

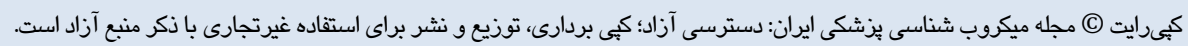

اطلاعات مقاله

تاريخجهُ مقاله

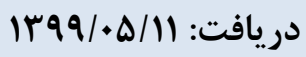

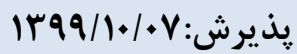

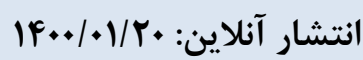

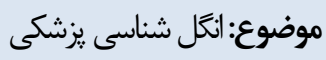

نويسندة مسئول: مرجان صباغيان ، گروه آندرولوزى، مركز تحقيقات يزشكى توليد مثل، يُوهشكده

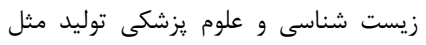

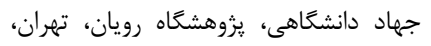

marjan.sabbaghian@gmail.com

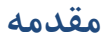

مركى در اثر ابتلا به بيمارى مالاريا در سال IV Y در ايران ثبت

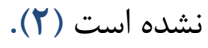

در خرخه زندگى يِيجيده انگل بلاسموديوم، انكلهاى مرحله

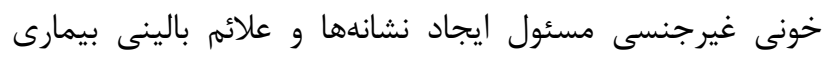

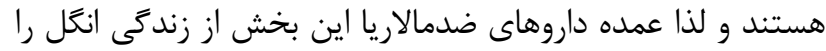

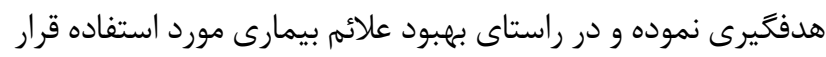

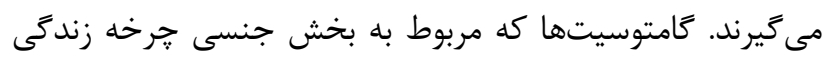
انكل هستند هيج نقشى در ايجاد علائم بيمارى ندارند ولى در انتقال انكل از ميزبان انسانى به ناقل يشه آنوفل ايفاى نقش مىنمايند (ب).
مالاريا يك بيمارى قابل يُشگيرى و قابل درمان و در عين

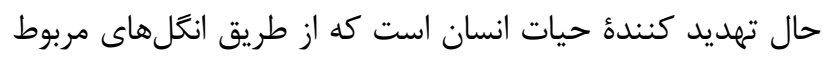

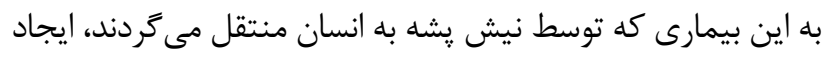

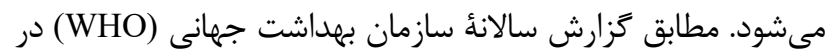

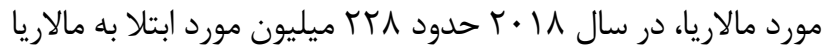

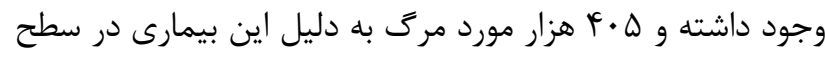

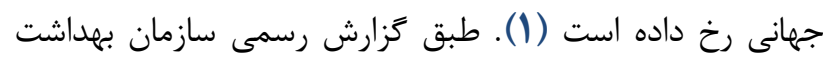

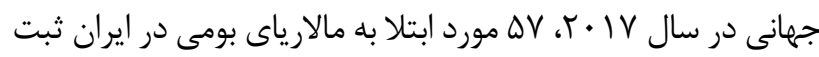

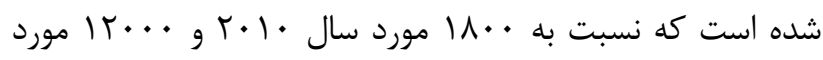
سال ... r، كاهش جشمخيرى را نشان مىدهد. علاوه بر اين، هيج 
كامتوسيت-اووكينت/اسيوروزوئيت در حال انجام است (ب). از جمله تستهاى سنجش جديد كه براى مرحله كامتوسيتى انكل نيز مورد

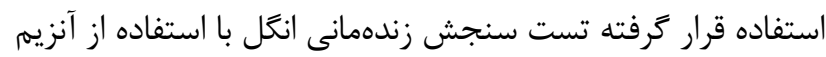

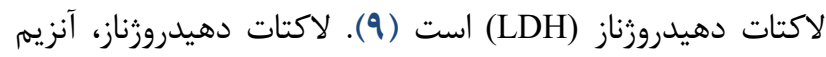

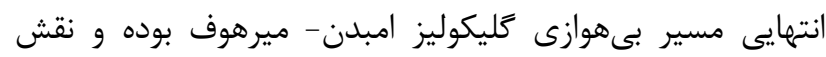
مهمى را در متابوليسم كربوهيدرات انكل هاى مالارياى انسانى بازى إنى

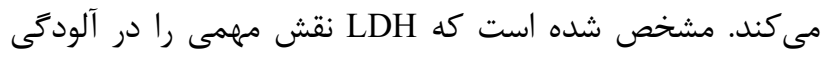

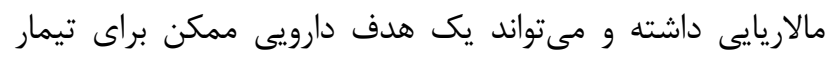

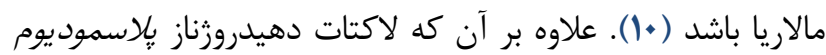

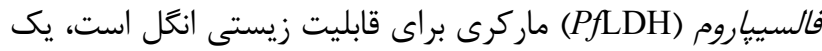

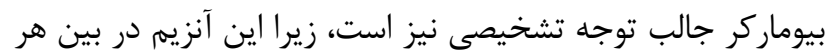

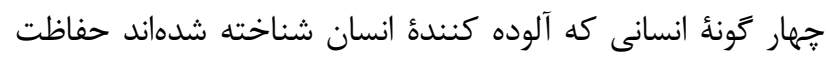
شده است (II). همجنين فعاليت PfLDH در كردش خون ميزبان

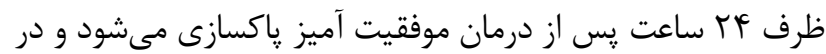
نتيجه تشخيص مثبت كاذب بسيار كمترى به واسطؤ ادامة حضور

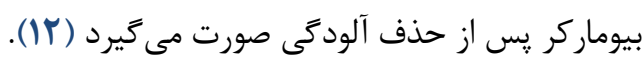
براى نائل شدن به حذف مالاريا، داروهاى ضدمالاريا يا

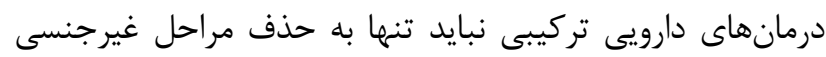

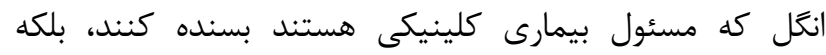

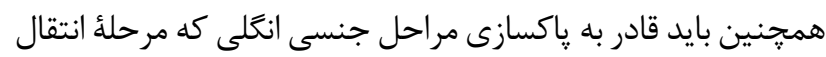
را حفظ مى كند نيز باشند. لذا نتايج جنين مطالعاتى مى توانند در جهت تهيه داروهاى مسدود كننده مرحله انتقال راهگشا باشند. ائوزين B يك رنخ آزمايشكاهى است كه يِشتر از طريق روشهاى داكينگ مولكولى قابليت ضدانكلى آن مطرح كرديده و اثر آنر

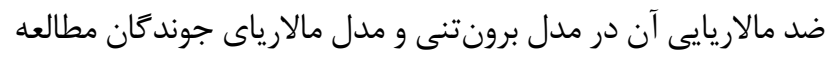

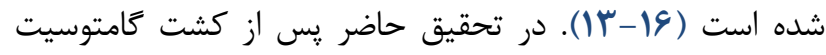

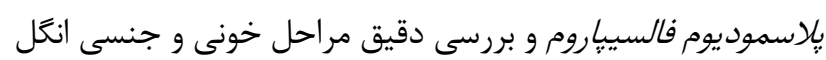

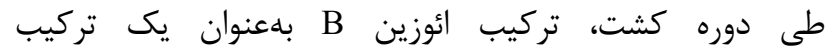
ضدكامتوسيت جديد مورد بررسى قرار كرفته و نتايج تيمار مراحل

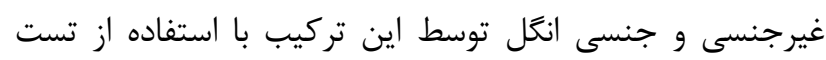
لاكتات دهيدروزناز مقايسه كرديده است.

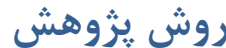

\section{كشت برونتنى انغل هاى مرحله غيرجنسى} يلاسموديوم فالسيياروم

كشت קِلاسموديوم فالسيياروم سويه 3D7 در دماى VT درجه

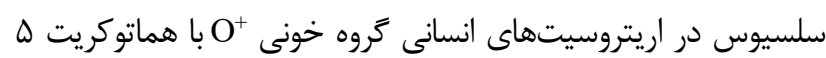

داروهايى كه مىتوانند كامتوسيتوزنز را كاهش دهند يا مىتوانند باعث كشته شدن كامتوسيتها گردند و كامتوسيتوسيد

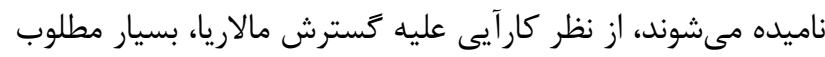
اند ولى هنوز تحت مطالعه قرار دارند كه علت اين امر فقدان الندان سنجشهاى با بازدهى بالاى كمى (مقدارى) است. اين داروهاى

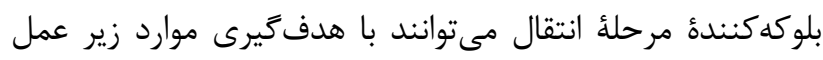
كنند: ا-كشتن مؤثر و كامل كامتوسيتهاى بالغ وقتى كه در ميزبان انسانى تشكيل مىشوند. r- مهار نمو كامتوسيتها به اووكينت و

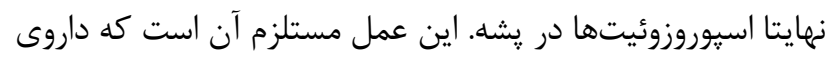

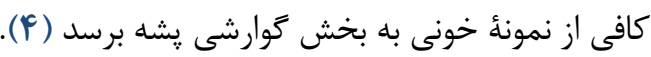

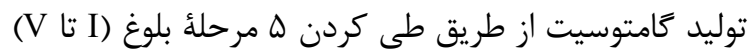
انجام مىشود و مرحلة V تنها شكلى است كه مىتواند باعث آلوده

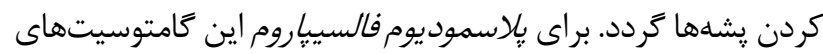

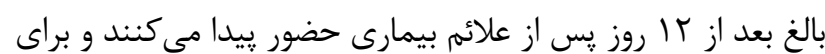

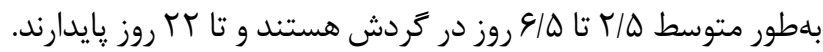
بنابراين كامتوسيتهاى در كردش مىتوانند فرايند انتقال مالاريا از

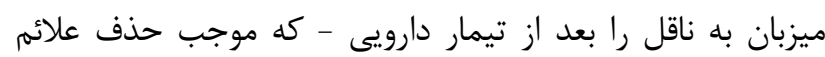
بيمارى مى كردد - حفظ نمايند (ه).

بيشتر داروهاى ضدمالارياى مورد تأييد فعلى شامل درمانهاى

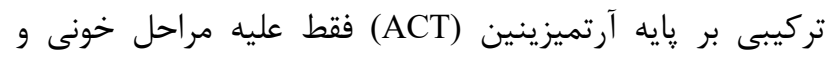

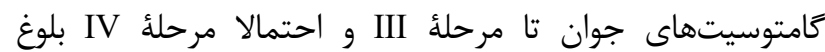
كامتوسيت مؤثر هستند. ضمنا بعضى تيمارهاى دارويى مانند كلروكوئين و سولفادوكسين - پيريمتامين سبب القاى كامتوسيتورنز كرديده و بنابراين بهطور مؤثرى در افزايش تعداد انتقال ها و بالا بردن ميزان آلودگى هاى جديد نقش دارند (9). در حال حاضر تنها داروى ضد مالاريايى كه بهطور مؤثر فعاليت كامتوسيتوسيدى دارد يريماكوئين است كه عليه كامتوسيتهاى

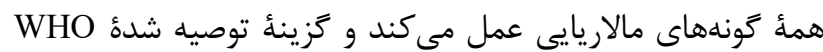
عليه گامتوسيتهاى بِاسموديوم فالسيباروم است. متاسفانه امكان

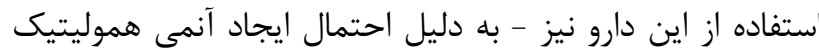

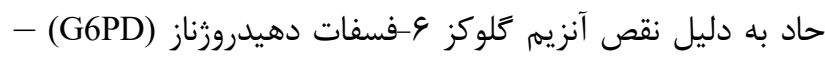
محدود است (V، A). به واسطة خطرات همراه با بريماكوئين، داروهاى بلوكه كننده مرحلة انتقال جديد به منظور رسيدن به هدف نهايى ريشهكنى مالاريا در حال حاضر به شدت مورد توجه هستند.

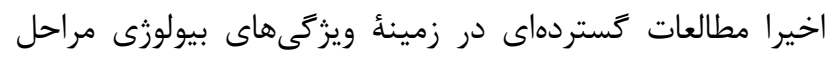

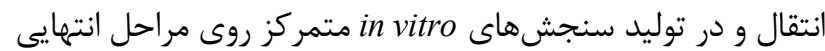
توليد گامتوسيت، كشنده بودن كامتوسيتهاى بالغ و انتقال 


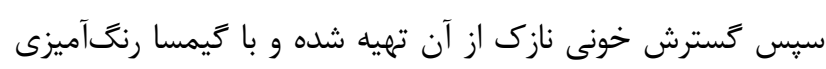

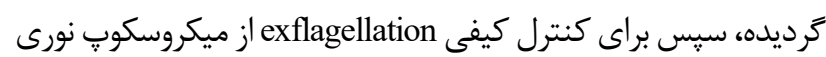

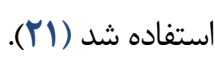

تست ائوزين B بر روى مرحله حلقه يلاسموديوم

\section{فالسيياروم}

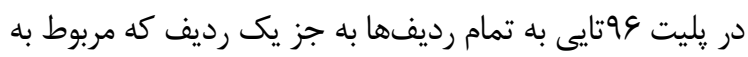

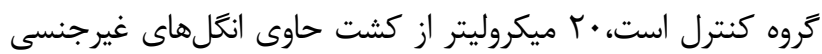

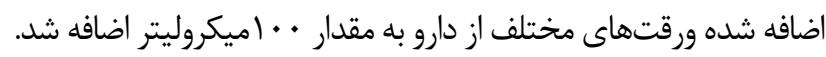

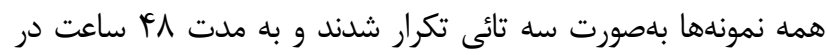
داخل انكوباتور

\section{تست ائوزين B بر روى عامتوسيت يلاسموديوم} فالسيياروم

در بليت عوتايى به تمام رديفها به جز يكى رديف كه مربوط به كروه كنترل است، • ب ميكروليتر از كشت حاوى كامتوسيت اضافه شده

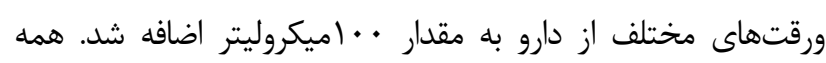

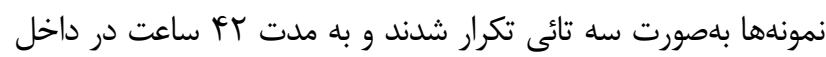
انكوباتور

\section{ارزيابى يارازيتمى و كامتوسيتمى از طريق سنجش آنزيم}

لاكتات دهيدروزناز يلاسموديوم فالسيياروم (PfLDH)

ارزيابى يارازيتمى از طريق سنجش آنزيم لاكتات دهيدروزناز يكى

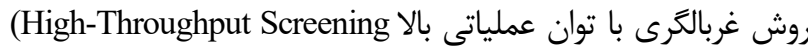
Assay)

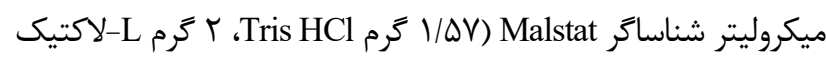

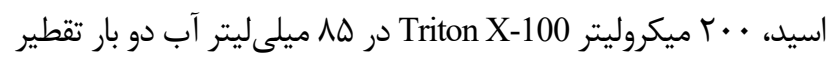
شده، 99 ميلى كرم ץ- استيل يِيريدين آدنين دىنوكلئوتيد (APAD)،

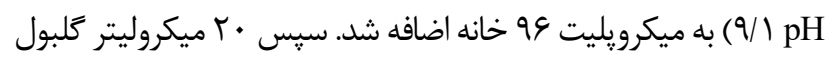

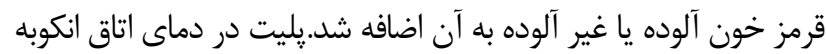

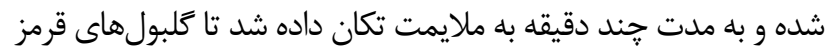
خونى حل شوند. در طول انكوباسيون، حجمهاى مساوى از Nitro Blue (PES) Phenazine Ethosulphateg Tetrazolium (NBT)

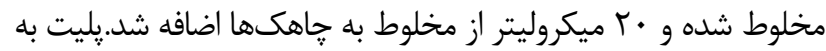

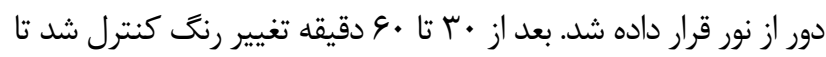
رنخ به ارغوانى تيره متمايل شد. يليت با استفاده از دستگاه BioTek PowerWave XS مد طول مور Mو

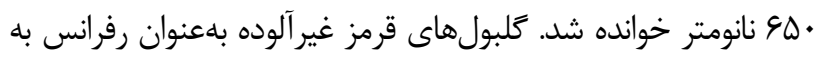

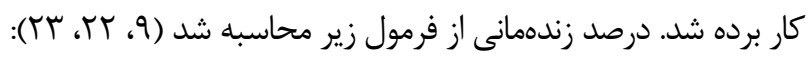

درصد انجام شد. محيط كشت مورد استفاده، محيط كشت كامل شامل ro HEPES به علاوه RPMI 1640 medium (Sigma-Aldrich)

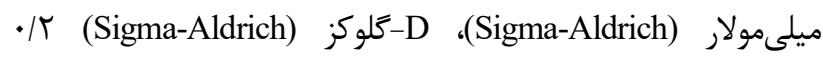

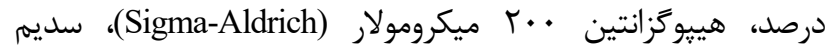

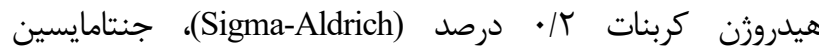

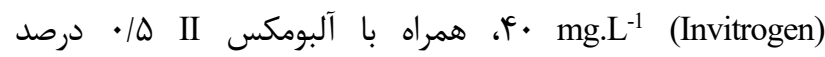
9 و سرم انسانى • ( درصد بود. انگل در اتمسفرى شامل (Invitrogen)

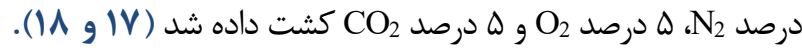
محيط كشت بلطور روزانه كازدهى شده و با محيط جديد (كرم

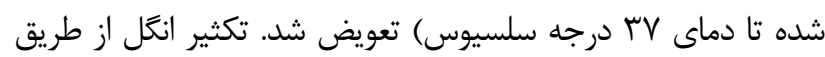
بررسى روزانه ميكروسكويى گسترشهاى نازى خونى رنغ شده با

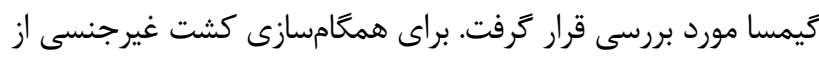

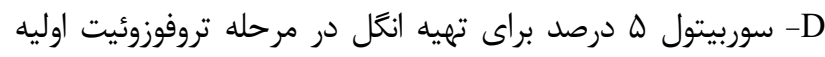

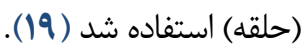

\section{القاى گامتوسيتوزنز و كشت كامتوسيت}

انغلهاى غيرجنسى كشت داده شدند تا درصد بارازيتمى به 9

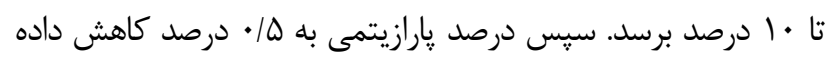

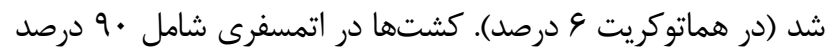
N2 N ه درصد $\mathrm{N}_{2}$

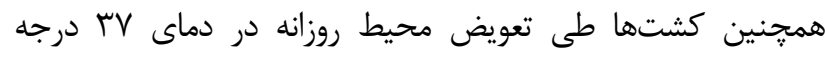

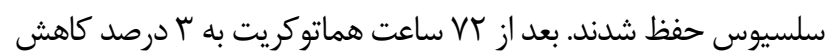

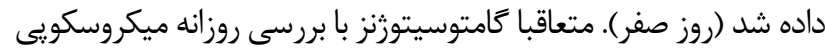

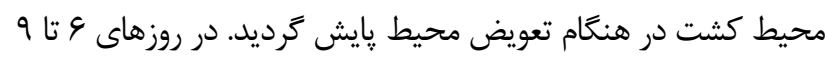

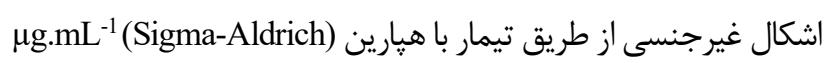

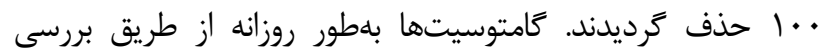

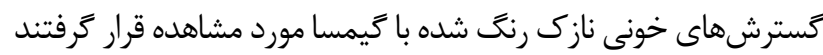

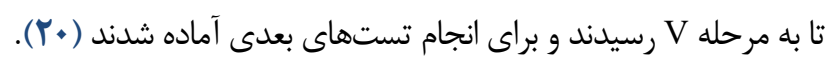

\section{كنترل كيفى توليد كامتوسيتهاى بالغ زنده با عملكرد}

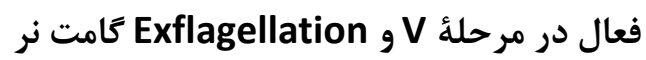
يس از توليد كامتوسيتهاى مرحلة V، در طول تعويض روزانه

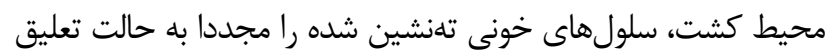

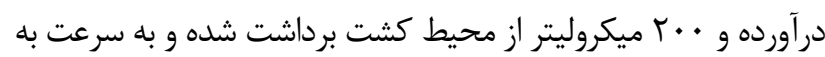

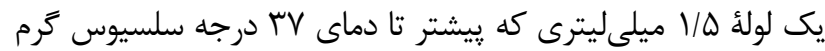

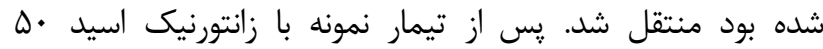

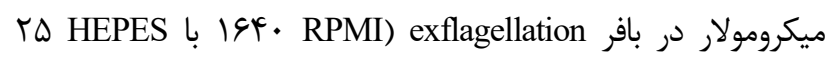

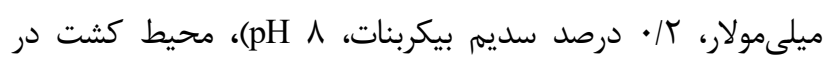

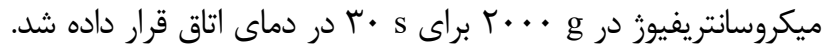


GraphPad Prism Version و و با استفاده از نرم افزار P-value<•••

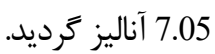

يافته ها

\section{كشت انكَل غير جنسى}

بعد از تنظيم شرايط كشت و استفاده از يروتئسي

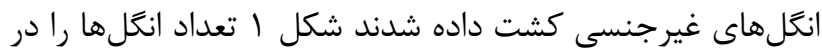

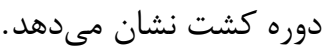

(نمونهى تيمار شده) XD - بc-) / (

زنده بودن

$$
\begin{aligned}
& \text { بc+ = ماي كامتوسيتهاى كنترل (c+) ميانگين }
\end{aligned}
$$

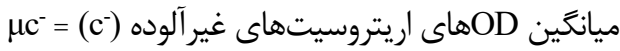

در اين مطالعه آزمونها ب بار تكرار شدند و نتايج توسط آزمون آناليز واريانس يك طرفه (One-way ANOVA) در سطح معنى دارى

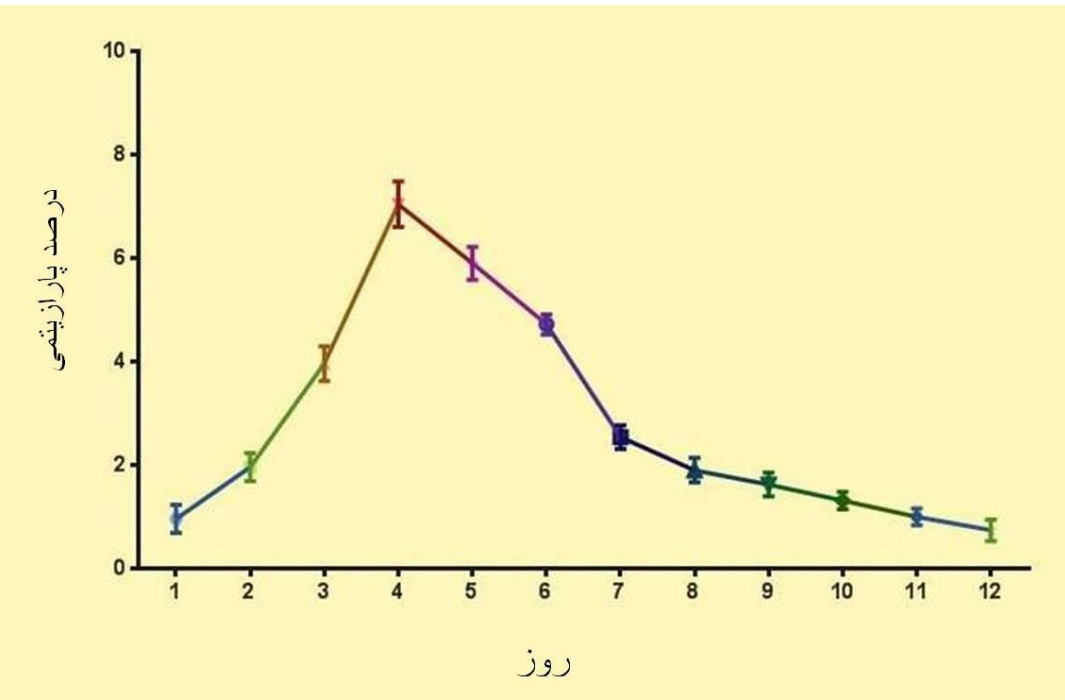

شكل ا. درصد بارازيتمى در طول كشت دورهاى كامتوسيت.

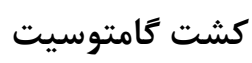

شكل r نشان مىدهد كه در روزهاى مختلف دوره كشت كدام مراحل انغل در محيط كشت يافت مىشوند.
جنان كه در شكل مشاهده مىشود تعداد انكل ها از آغاز دوره

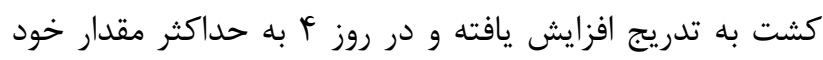

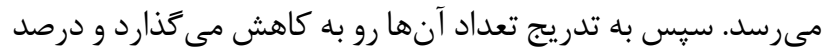

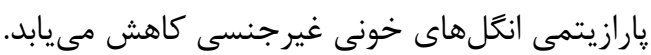

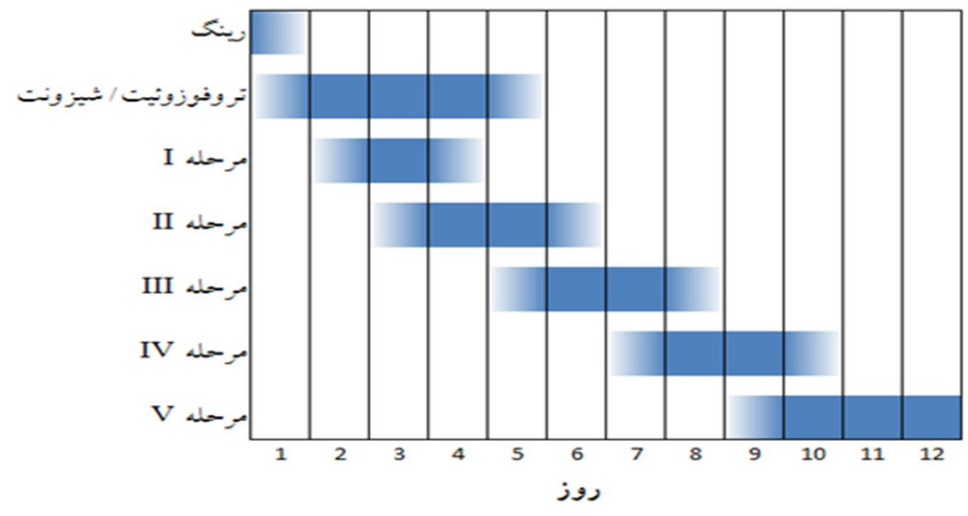

شكل r. مراحل مختلف انكل بلاسموديوم فالسيياروم 3D7 در طول دورة كشت كَامتوسيت. 
و (V) به ترتيب در روزهاى دوم تا هشتم و هفتم تا دوازدهم در محيط مشاهده شدند.
شكل نشان مىدهد مراحل غيرجنسى در حدود روزهاى اول

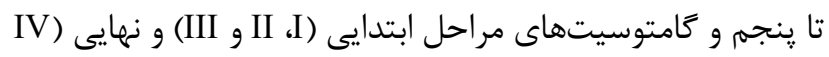

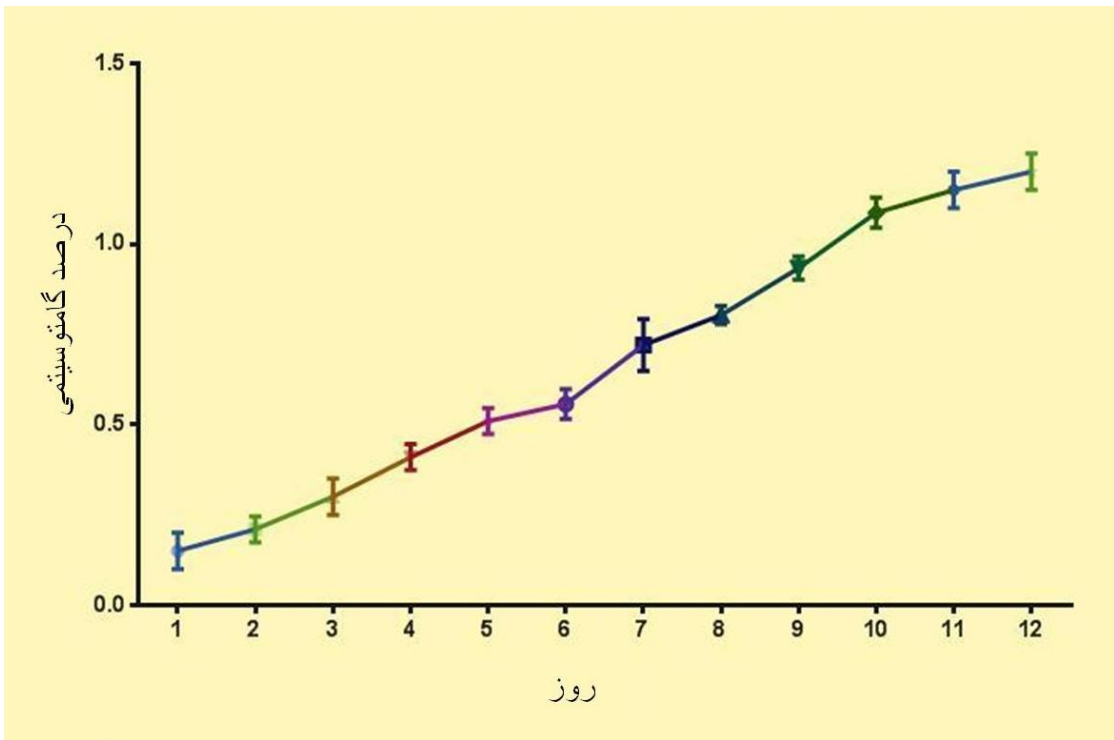

شكل rا. درصد كامتوسيتمى در طول كشت دورهاى كامتوسيت.

با بلوغ كامتوسيت (مرحله V) به حداكثر مقدار خود مىرسد. در

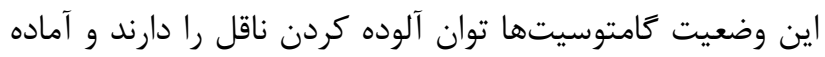
براى انجام تست تركيب ضد كامتوسيت هستند.
تغييرات تعداد كامتوسيتها در طول دوره كشت

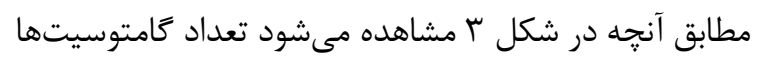

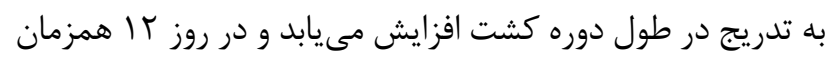

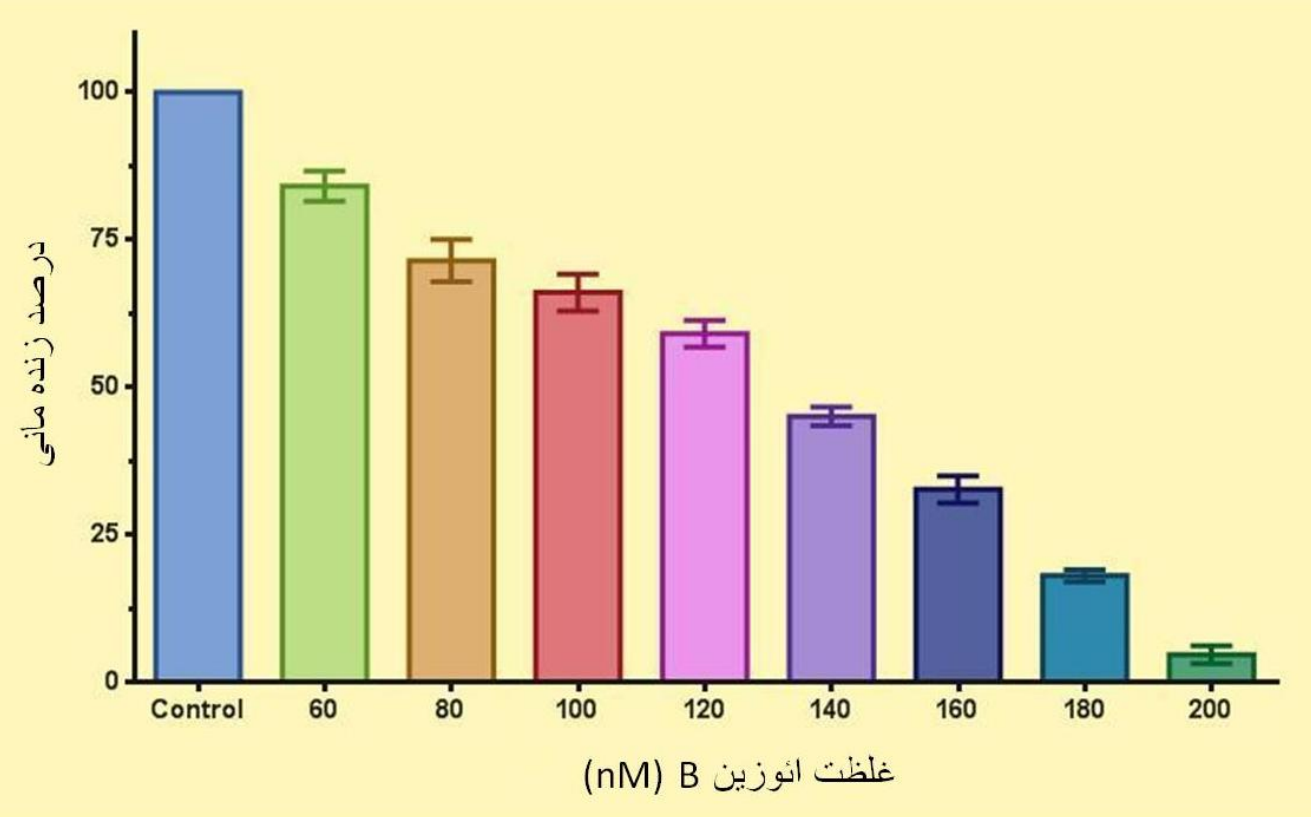

شكل F. تاثير ائوزين B بر رينكَ انكَل بلاسموديوم فالسيباروم 3D7. درصد زندهمانى در مقايسه با كروه كنترل براى هر كروه تست نشان داده شده است.

(Means \pm SEM ( $=5 \& P<0.05)$, One Way-ANOVA test with Graph Pad prism version 7.05) 
در شكل ه تاثير ائوزين B و داروهاى كنترل كلروكين و

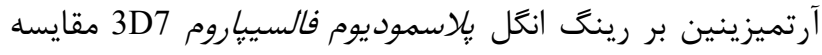

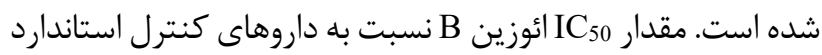

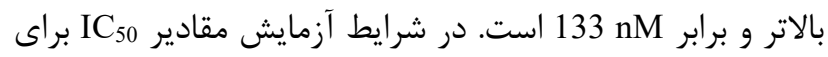

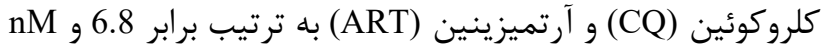

تأثير ائوزين B بر مراحل غيرجنسى انكل بلاسموديوم فالسييا روم

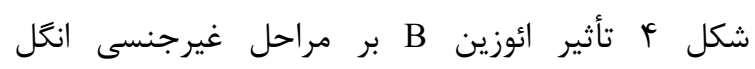

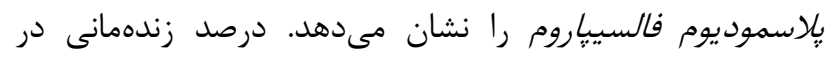

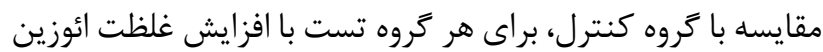

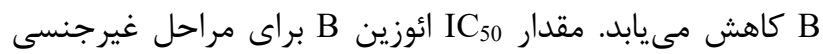
انغل nM n 133 است.

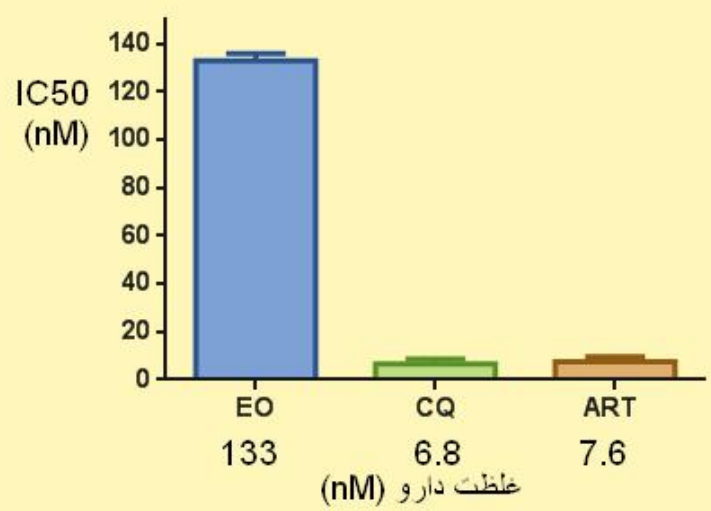

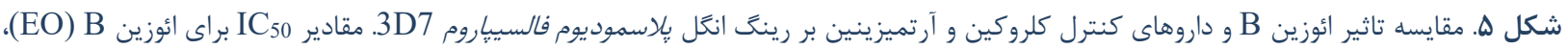

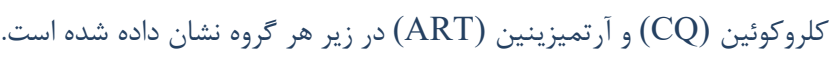

(Means $\pm \operatorname{SEM}(\mathrm{n}=5 \& P<0.05)$, One Way-ANOVA test with Graph Pad prism version 7.05)

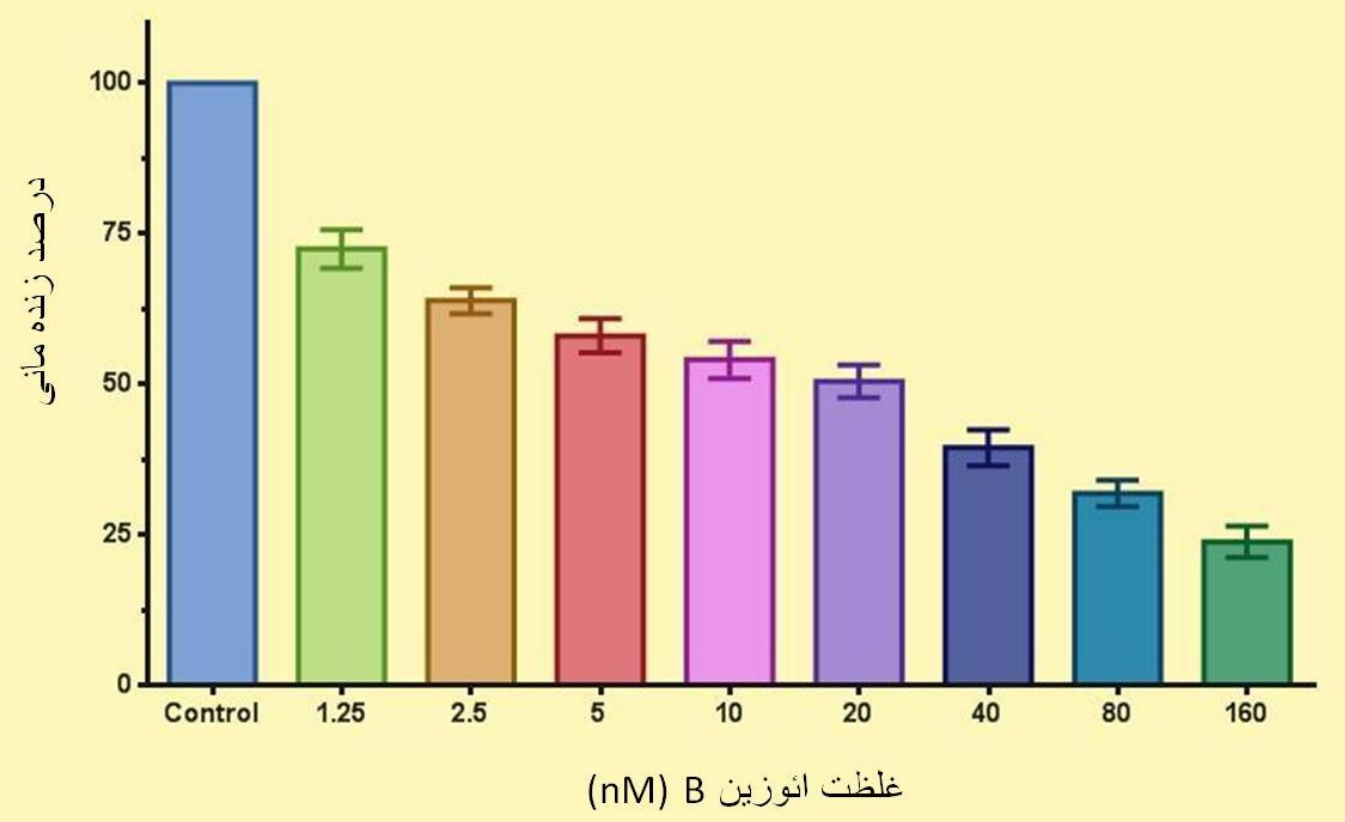

شكل 9. تاثير ائوزين B بر كامتوسيت انكل بِاسموديوم فالسيباروم 3D7.

(Means \pm SEM $(\mathrm{n}=5 \& P<0.05)$, One Way-ANOVA test with Graph Pad prism version 7.05) 
كامتوسيتها هستند نيز مورد هدف داروهاى كنترل كننده مرحله

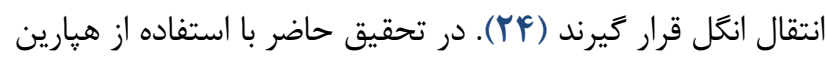

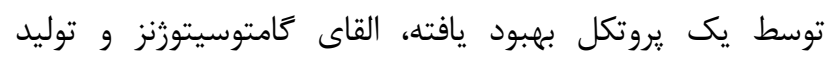

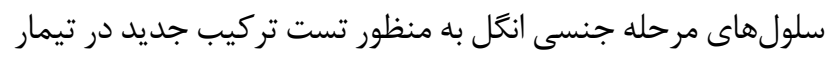

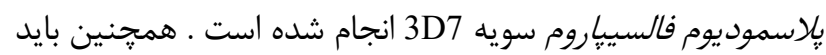

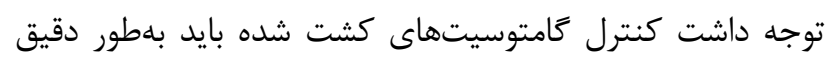

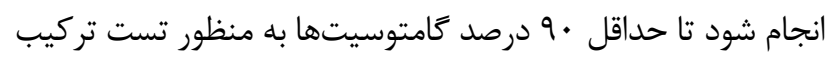

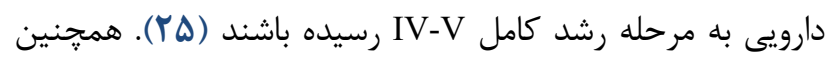

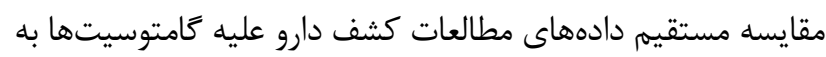

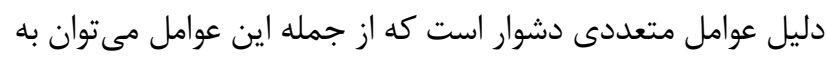

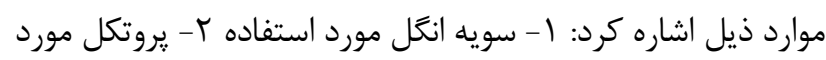

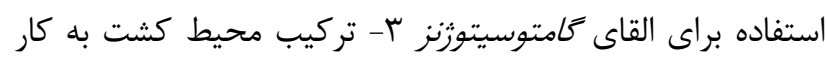

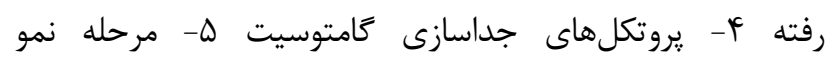

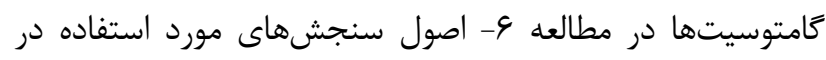

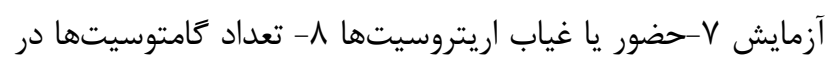

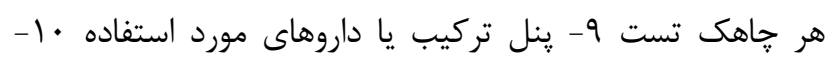

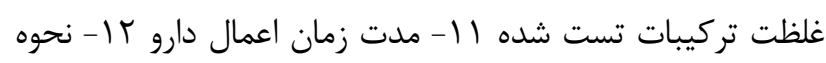

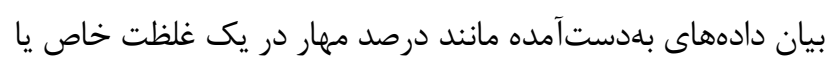

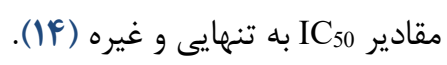

ائوزين B بر روى انكل Toxoplasma gondii و مرحله خونى

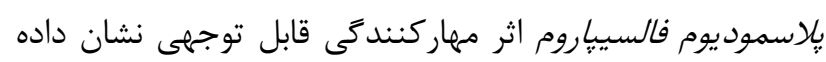

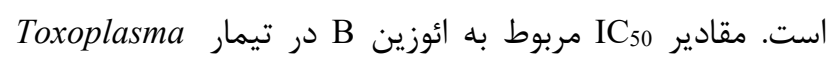
gondii

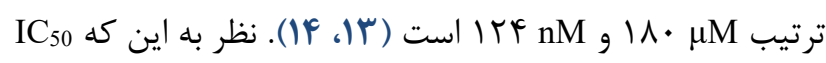

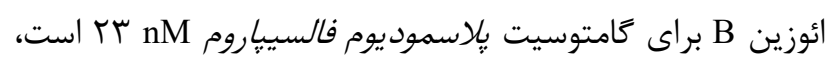

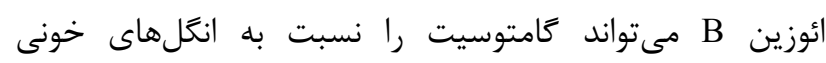

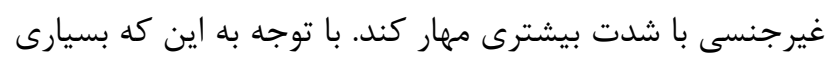

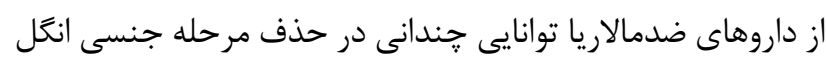

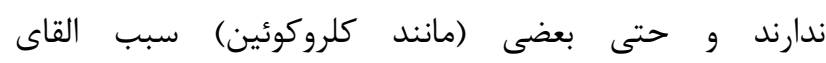

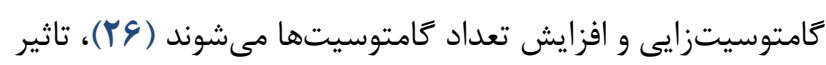

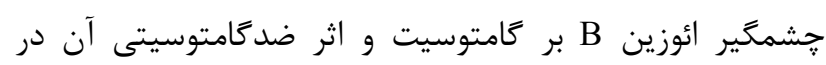

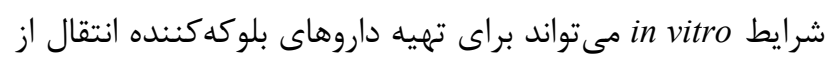

$$
\text { انسان به يشه مورد توجه قرار كيرد. }
$$

تركيب متيلن بلو نيز كه يك رنغ مورد استفاده در آزمايشكاه

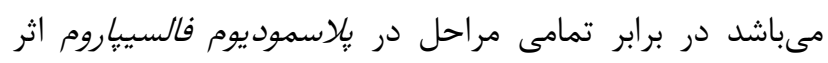

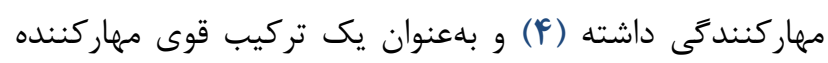

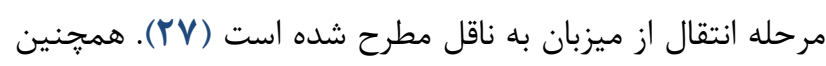

تأثير ائوزين B بر كامتوسيت انگل بلاسموديوم فالسييا روم ت بكاير

شكل 4 تأثير ائوزين B بر كامتوسيت انگل بلاسموديوم

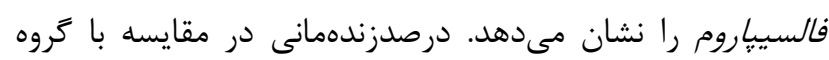

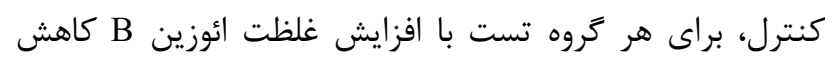

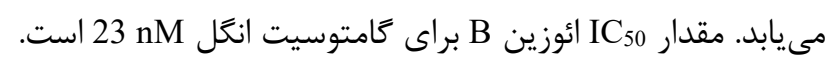

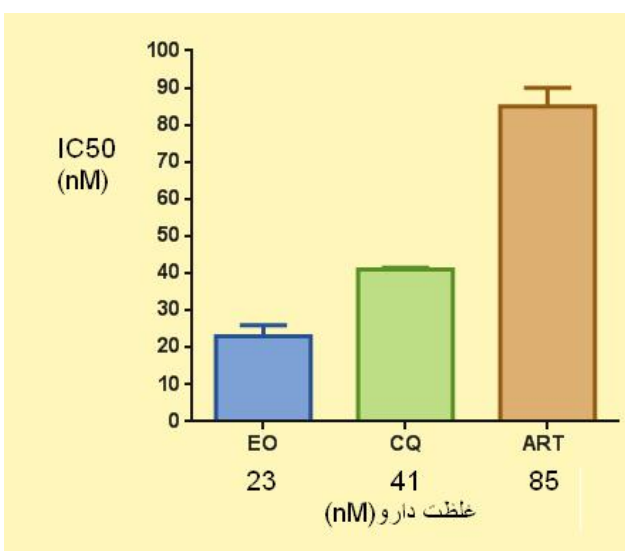

شكل V. مقايسه تاثير ائوزين B و داروهاى كنترل كلروكين و آرتميزينين بر كامتوسيت انكل ٍإسمود يوم فالسيإروم

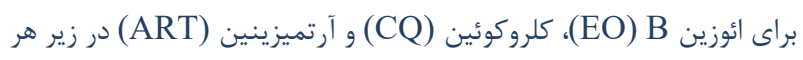
كروه نشان داده شده است.

(Means \pm SEM ( $n=5 \& P<0.05)$, One WayANOVA test with Graph Pad prism version 7.05)

در شكل V تاثير ائوزين B و داروهاى كنترل كلروكوئين و

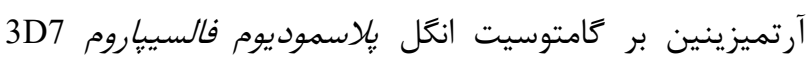

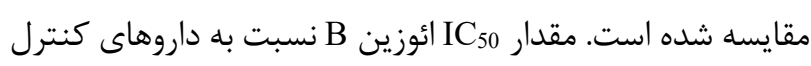

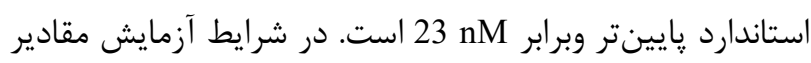

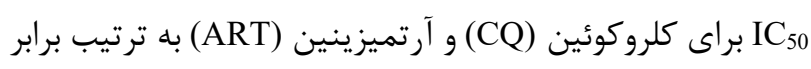

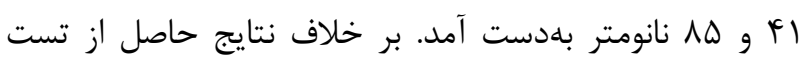

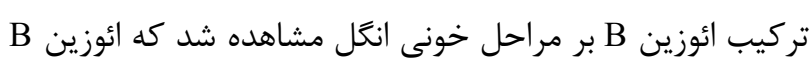

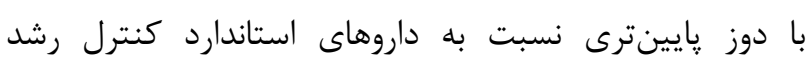
كامتوسيت را مهار نموده كه بيانكر تاثير مهارى قابل توجه ائوزين الوزين B بر كامتوسيت است. كنترل پايدار بيمارى مالاريا در صورتى محقق مى گردد كه

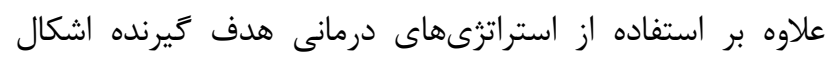

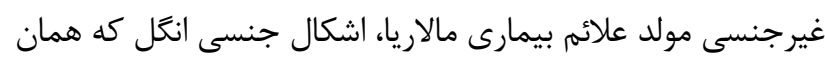


جنسى انگل بِلاسموديوم فالسيياروم نزديك و يا بالاتر از بعضى

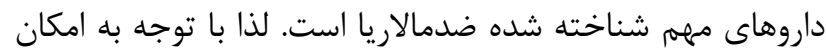

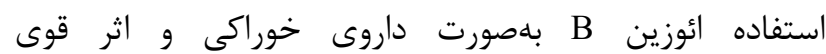
ضدكامتوسيتى آن در مقايسه با بعضى داروهاى مرسوم، اين تركيب

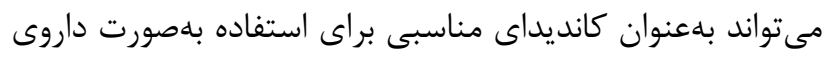

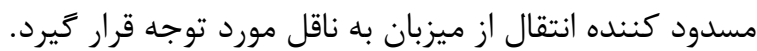

$$
\text { نتيجها تيرى }
$$

با توجه به تاثير معنى دار ائوزين B بر تعداد كامتوسيتها و

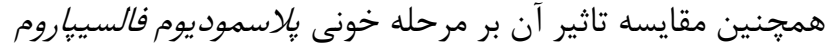

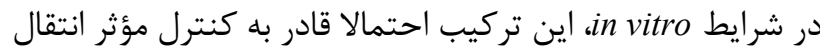

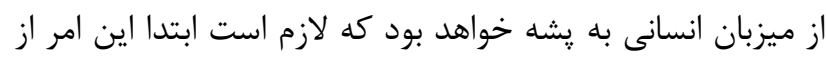

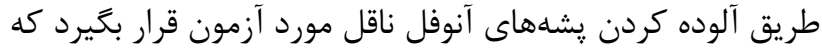

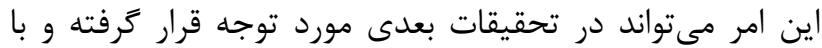
استفاده از آزمون استاندارد Membrane-Feeding Assay كه تهرد آزمون استاندارد طلايى براى بررسى مسدود كردن انتقال است آنت

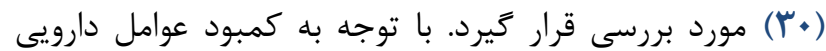
شناخته شده مسدودكننده انتقال از انسان به ناقل، شناسايى

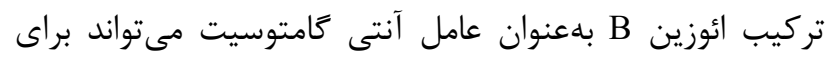
تحقيقات آتى حائز اهميت باشد.

$$
\text { سياسخَزارى }
$$

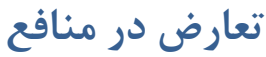

نويسندكان هيج كونه تعارضى در منافع گزارش نكردند.

$$
\text { منابع مالى ندارد. }
$$

ناثير قابل توجه آن بر كامتوسيت اين انكل از طريق تغيير شكل مورفولوزيكى كامتوسيتها اخيرا كزارش شده است (Y^). مقدار

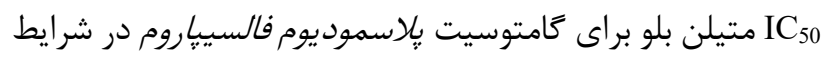
In vitro ائوزين B به اين تركيب نزديك است كه نشاندهنده كار آيى بالاى ائوزين B عليه مرحلئ جنسى انكل است.

در مقايسه با داروهاى اصلى ضدمالاريا مىتوان اشاره نمود آرتميزينين كه يك داروى مههم ضدمالاريا بهويزه در درمانهاى

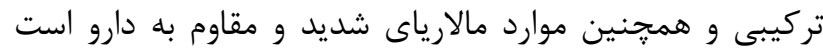

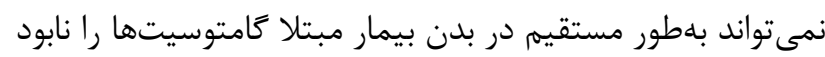

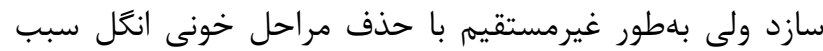

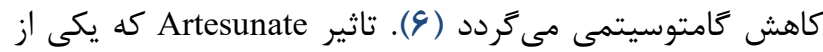

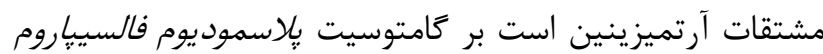

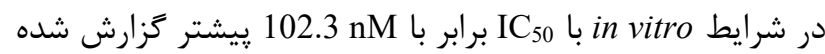
است (TY). همجنين ثريماكوئين كه تنها داروى مورد استفاده in vitro باصورت بالينى براى حذف كامتوسيت مىباشد در شرايط

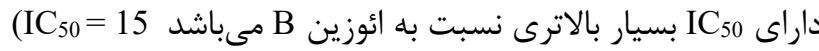
هM)

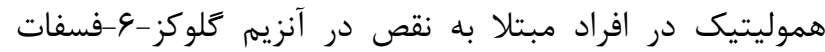

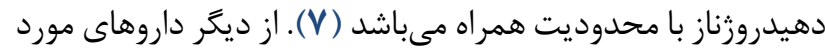
استفاده بالينى عليه مراحل خونى مالاريا مىتوان به كيه كينين و

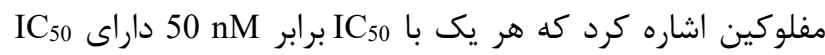

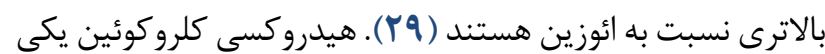

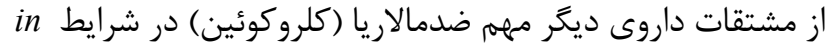

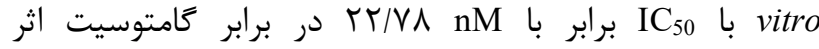

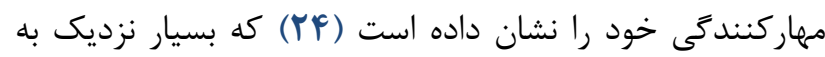

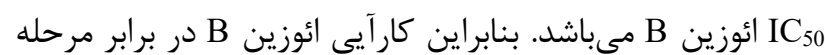

4. Gaur D, Chitnis CE, Chauhan VS, editors. Advances in malaria research. John Wiley \& Sons, Incorporated; [DOI: 10.1002/9781118493816]

5. Biamonte MA, Wanner J, Le Roch KG. Recent advances in malaria drug discovery. Bioorg Med Chem Lett. 2013 May 15;23(10):2829-43. [DOI:10.1016/j.bmcl.2013.03.067] [PMID] [PMCID] 
6. Abdul-Ghani R, Basco LK, Beier JC, Mahdy MA. Inclusion of gametocyte parameters in anti-malarial drug efficacy studies: filling a neglected gap needed for malaria elimination. Malar J. 2015 Dec;14(1):16. [DOI:10.1186/s12936-015-0936-4] [PMID] [PMCID]

7. Pukrittayakamee S, Chotivanich K, Chantra A, Clemens R, Looareesuwan S, White NJ. Activities of artesunate and primaquine against asexual-and sexual-stage parasites in falciparum malaria. Antimicrob Agents Chemother. 2004 Apr 1;48(4):1329-34.. [DOI:10.1128/AAC.48.4.13291334.2004] [PMID] [PMCID]

8. Staines HM, Krishna S, editors. Treatment and prevention of malaria: antimalarial drug chemistry, action and use. Springer Science \& Business Media; 2012 Jan 5. [DOI:10.1007/978-3-0346-0480-2]

9. World Health Organization (2012) Management of severe malaria: a practical handbook, 3rd edn. WHO, Geneva,

http://www.who.int/iris/bitstream/10665/79317/1/97 89241548526 eng.pdf?ua $=1$

10. D'alessandro S, Silvestrini F, Dechering K, Corbett Y, Parapini S, Timmerman M, Galastri L, Basilico N, Sauerwein R, Alano P, Taramelli D. A Plasmodium falciparum screening assay for anti-gametocyte drugs based on parasite lactate dehydrogenase detection. J Antimicrob Chemother. 2013 Sep 1;68(9):2048-58. [DOI:10.1093/jac/dkt165] [PMID]

11. Markwalter CF, Davis KM, Wright DW. Immunomagnetic capture and colorimetric detection of malarial biomarker Plasmodium falciparum lactate dehydrogenase. Anal Biochem. 2016 Jan 15;493:304. [DOI:10.1016/i.ab.2015.10.003] [PMID]

12. Brown WM, Yowell CA, Hoard A, Vander Jagt TA, Hunsaker LA, Deck LM, Royer RE, Piper RC, Dame JB, Makler MT, Vander Jagt DL. Comparative structural analysis and kinetic properties of lactate dehydrogenases from the four species of human malarial parasites. Biochemistry. 2004 May 25;43(20):6219-29. [DOI:10.1021/bi049892w] [PMID]

13. Iqbal J, Siddique A, Jameel M, Hira PR. Persistent histidine-rich protein 2, parasite lactate dehydrogenase, and panmalarial antigen reactivity after clearance of Plasmodium falciparum monoinfection. J Clin Microbiol. 2004 Sep 1;42(9):4237-41. [DOI: 10.1128/]CM.42.9.42374241.2004] [PMID] [PMCID]

14. Atreya CE, Johnson EF, Irwin JJ, Dow A, Massimine KM, Coppens I, Stempliuk V, Beverley S, Joiner KA, Shoichet BK, Anderson KS. A molecular docking strategy identifies Eosin B as a non-active site inhibitor of protozoal bifunctional thymidylate synthase-dihydrofolate reductase. J Biol Chem. 2003
Apr

$18 ; 278(16): 14092-100$ [DOI:10.1074/jbc.M212690200] [PMID]

15. Massimine KM, McIntosh MT, Doan LT, Atreya CE, Gromer S, Sirawaraporn W, Elliott DA, Joiner KA, Schirmer RH, Anderson KS. Eosin B as a novel antimalarial agent for drug-resistant Plasmodium falciparum. Antimicrob Agents Chemother. 2006 Sep 1;50(9):3132-41. [DOI:10.1128/AAC.0062106] [PMID] [PMCID]

16. Zamani Z, Tafreshi AS, Nahrevanian H, Lame-Rad B, Pourfallah F, Eslamifar H, Sadeghi S, Vahabi F, Iravani A, Arjmand M. Efficacy of eosin B as a new antimalarial drug in a murine model. Malar Res Treat. 2012;2012. [DOI:10.1155/2012/381724] [PMID] [PMCID]

17. Federal Register, D\&C Red no. 21 and D\&C Red no. 22. Federal Register vol. 47, pp. 53843-53846, 1982.

18. Trager W, Jensen JB. Human malaria parasites in continuous culture. J Parasitol. 2005 Jun;91(3):4846. 3395(2005)091[0484:HMPICC]2.0.CO;2]

19. Allen RJ, Kirk K. Plasmodium falciparum culture: the benefits of shaking. Mol Biochem Parasit. 2010 Jan $1 ; 169(1): 63-5$.

[DOI: 10.1016/j.molbiopara.2009.09.005] [PMID]

20. Fivelman QL, McRobert L, Sharp S, Taylor CJ, Saeed M, Swales CA, Sutherland CJ, Baker DA. Improved synchronous production of Plasmodium falciparum gametocytes in vitro. Mol Biochem Parasit. 2007 Jul 1;154(1):119-23. [DOI: 10.1016/j.molbiopara.2007.04.008] [PMID]

21. Carter R, Ranford-Cartwright L, Alano P. The culture and preparation of gametocytes of Plasmodium falciparum for immunochemical, molecular, and mosquito infectivity studies. Protocols in Molecular Parasitology. 1993 (pp. 67-88). Humana Press. [DOI: 10.1385/0-89603-239-6:67] [PMID]

22. Reader J, Botha M, Theron A, Lauterbach SB, Rossouw C, Engelbrecht D, Wepener M, Smit A, Leroy D, Mancama D, Coetzer TL. Nowhere to hide: interrogating different metabolic parameters of Plasmodium falciparum gametocytes in a transmission blocking drug discovery pipeline towards malaria elimination. Malar J. 2015 Dec 1;14(1):213. [DOI:10.1186/s12936-015-0718-z] [PMID] [PMCID]

23. Makler MT, Hinrichs DJ. Measurement of the lactate dehydrogenase activity of Plasmodium falciparum as an assessment of parasitemia. Am J Trop Med Hyg. 1993 Feb $1 ; 48(2): 205-10$ 
24. Makler MT, Ries JM, Williams JA, Bancroft JE, Piper RC, Gibbins BL, Hinrichs DJ. Parasite lactate dehydrogenase as an assay for Plasmodium falciparum drug sensitivity. Am J Trop Med Hyg. 1993 Jun 1;48(6):739-41. [DOI: 10.4269/ajtmh.1993.48.739] [PMID]

25. Peatey CL, Spicer TP, Hodder PS, Trenholme KR, Gardiner DL. A high-throughput assay for the identification of drugs against late-stage Plasmodium falciparum gametocytes. Mol Biochem Parasit. 2011 Dec $1 ; 180(2): 127-31$.

[DOI:10.1016/j.molbiopara.2011.09.002] [PMID]

26. Ngwa C, Rosa TF, Pradel G. The biology of malaria gametocytes. Current Topics in Malaria. 2016 Nov 30:117-44. [DOI: 10.5772/65464]

27. Dechy-Cabaret O, Benoit-Vical F. Effects of antimalarial molecules on the gametocyte stage of Plasmodium falciparum: the debate. J Med Chem. 2012 Dec 13;55(23):10328-44. [DOI:10.1021/jm3005898] [PMID]

28. Adjalley SH, Johnston GL, Li T, Eastman RT, Ekland EH, Eappen AG, Richman A, Sim BK, Lee MC, Hoffman SL, Fidock DA. Quantitative assessment of Plasmodium falciparum sexual development reveals potent transmission-blocking activity by methylene blue. P Natl A Sci. 2011 Nov 22;108(47):E1214-23.

[DOI: 10.1073/pnas.1112037108] [PMID] [PMCID]

29. Wadi I, Pillai CR, Anvikar AR, Sinha A, Nath M, Valecha N. Methylene blue induced morphological deformations in Plasmodium falciparum gametocytes: implications for transmission-blocking. Malar J. $2018 \quad$ Dec 1;17(1):11. [DOI:10.1186/s12936-017-2153-9] [PMID] [PMCID]

30. Peatey CL, Skinner-Adams TS, Dixon MW, McCarthy JS, Gardiner DL, Trenholme KR. Effect of antimalarial drugs on Plasmodium falciparum gametocytes. J Infect Dis. 2009 Nov 15;200(10):1518-21. [DOI:10.1086/644645] [PMID]

31. Delves MJ, Straschil U, Ruecker A, Miguel-Blanco C, Marques S, Dufour AC, Baum J, Sinden RE. Routine in vitro culture of $\mathrm{P}$. falciparum gametocytes to evaluate novel transmission-blocking interventions. Nat Protoc. 2016 Sep;11(9):1668-80. [DOI:10.1038/nprot.2016.096] [PMID] 